\title{
Rapid Monitoring of Bacteria and Fungi aboard the International Space Station (ISS)
}

\author{
J. Maule ${ }^{1}$ and N. Wainwright ${ }^{2}$ \\ British Aerospace (BAE) Systems, Huntsville, AL, 35806; and Charles River Laboratories, Charleston, SC 29407 \\ A. Steele ${ }^{3}$ \\ Geophysical Laboratory, Carnegie Institution for Science, Washington, DC, 20015 \\ D. Gunter, G. Flores and M. Effinger ${ }^{4}$ \\ NASA MSFC, Huntsville, AL 35812 \\ M. Damon and M. Wells ${ }^{5}$ \\ British Aerospace (BAE) Systems, Huntsville, AL, 35806; and University of Alabama at Huntsville (UAH), \\ Huntsville AL 35806 \\ S. Williams ${ }^{6}$ \\ Astronaut Office, NASA Johnson Space Center, Houston, TX, 77058 \\ H. Morris and L. Monaco \\ Jacobs Technology Inc., Huntsville, AL 35806
}

\begin{abstract}
Microorganisms within spacecraft have traditionally been monitored with culture-based techniques. These techniques involve growth of environmental samples (cabin water, air or surfaces) on agar-type media for several days, followed by visualization of resulting colonies or return of samples to Earth for ground-based analysis. Data obtained over the past 4 decades have enhanced our understanding of the microbial ecology within space stations. However, the approach has been limited by the following factors: i) Many microorganisms (estimated $>95 \%$ ) in the environment cannot grow on conventional growth media; ii) Significant time lags (3-5 days for incubation and up to several months to return samples to ground); iii) Condensation in contact slides hinders colony counting by crew; and iv) Growth of potentially harmful microorganisms, which must then be disposed of safely. This report describes the operation of a new culture-independent technique onboard the ISS for rapid analysis (within minutes) of endotoxin and $\beta$-1, 3-glucan, found in the cell walls of gramnegative bacteria and fungi, respectively. The technique involves analysis of environmental samples with the Limulus Amebocyte Lysate (LAL) assay in a handheld device, known as the Lab-On-a-Chip Application Development Portable Test System (LOCAD-PTS). LOCADPTS was launched to the ISS in December 2006, and here we present data obtained from Mach 2007 until the present day. These data include a comparative study between LOCADPTS analysis and existing culture-based methods; and an exploratory survey of surface endotoxin and $\beta$-1, 3-glucan throughout the ISS. While a general correlation between LOCAD-PTS and traditional culture-based methods should not be expected, we will suggest new requirements for microbial monitoring based upon culture-independent parameters measured by LOCAD-PTS.
\end{abstract}

\footnotetext{
${ }^{1}$ Project Scientist, LOCAD-PTS, British Aerospace (BAE) Systems, Huntsville, AL, 35806

${ }^{2}$ Principal Investigator, LOCAD-PTS, Charles River Labs, Wappoo Road, Charleston, SC, 29407.

${ }^{3}$ Staff Scientist, Geophysical Laboratory, Carnegie Institution for Science, Washington DC, 20015.

${ }^{4}$ Lead Flight Operations Engineer and Project Managers (past and present), LOCAD Group, MSFC, Huntsville, AL, 35812.

${ }^{5}$ Scientist, BAE Systems, Huntsville, AL, 35806; Engineer, UAH, Huntsville, AL, 35806.

${ }^{6}$ Deputy Chief, Astronaut Office, NASA Johnson Space Center, Houston, TX, 77058.

${ }^{7}$ Scientist and Science Team Lead, Jacobs Technology Inc., Huntsville, AL, 35805.
} 


\section{Introduction}

The International Space Station (ISS) is an enclosed habitat, where crews of three to six astronauts live and work for several months at a time. It was recognized early on in the history of the space program that microorganisms might pose a health hazard to the crew if left unmonitored ${ }^{1}$. Since the first space flight, by Yuri Gagarin in 1961, microorganisms within spacecraft have traditionally been analyzed with culture-based techniques, both in the United States $^{2-5}$ and Russia ${ }^{6-13}$.

The current microbial requirements for the ISS are shown in Table 1 below. These requirements are currently verified by the Crew Health Care System (CHeCS), an onboard kit consisting of various culture-based methods for the analysis of air and water, as well as surfaces. Surfaces are analyzed with 'Contact Slides' (Biotest, Rocaway, $\mathrm{NJ}$ ), applied to a surface, incubated for 3-5 days, followed by visualization of colonies. More sophisticated analyses are performed on the ground following the return of flight samples to NASA Johnson Space Center.

Table 1. Current Microbial Requirements for Internal Surfaces of the International Space Station (ISS)

\begin{tabular}{|c|c|c|}
\hline \multirow{2}{*}{ MISSION PHASE } & \multicolumn{2}{|c|}{ Colony Forming Units (CFU)/100 $\mathbf{c m}^{\mathbf{2}}$} \\
\cline { 2 - 3 } & Bacteria (CFU) & Fungi (CFU) \\
\hline In-flight & 10000 & 100 \\
\hline Pre-flight & 500 & 10 \\
\hline
\end{tabular}

Requirements from ${ }^{1}$ ISS Mission Operations Requirements Document (MORD) section "7.4.4: In-flight environmental microbiology specifications and monitoring of air and surfaces" and "7.4.3 Preflight Environmental Microbiology Specifications and Monitoring of Air and Surfaces".

These culture-based techniques have provided extremely useful data regarding the type and distribution of microorganisms in space stations, from Salyut ${ }^{13}$ to the ISS $^{2}$. However, as with all techniques, there are several limitations; in this case, of using a system to detect microorganisms based on their ability to grow on culture media. Four of these limitations include: i) More than 95\% microbial species cannot be cultured in conventional growth media ${ }^{14-15 ;}$ ii) Significant time lags often occur between onboard sampling and colony visualization (3-5 days) and groundbased analysis (as long as several months); iii) Colonies are often difficult to visualize due to condensation within contact slide media plates (see Fig. 1); iv) Culture-based techniques involve growth of potentially harmful microorganisms, which must then be disposed of safely.

There are a variety of techniques used to detect microorganisms, each suitable to a particular purpose. These techniques may test parameters such as a microorganism's ability to grow, metabolic activity, or the presence of characteristic biological molecules. The Lab-On-a-Chip Application Development

Portable Test System (LOCAD-PTS) detects the latter i.e., the presence of biological molecules found in the cell walls of bacteria and fungi. These molecules include: i) Endotoxin, ii) $\beta-1,3$-glucan and iii) lipoteichoic acid/peptidoglyan.

A common classification in microbiology is to divide bacteria into two groups:

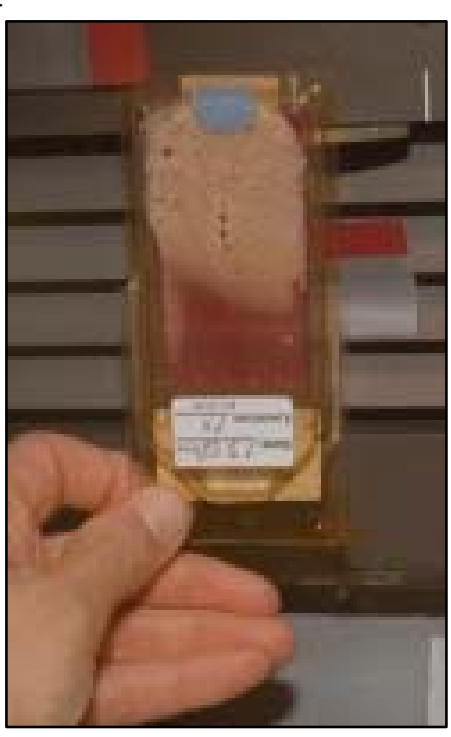

Figure 1. Condensation within a 'Contact Slide' onboard ISS Gram-negative and Gram-positive. The 'Gram' refers to the Gram stain, developed by Hans Christian Gram in 1884, to differentiate Klebsiella pneumoniae from pneumococci ${ }^{16}$. With this method, Gram-negative bacteria stain pink and Gram-positive bacteria stain purple, and is related to structure of their cell walls. Endotoxin - the bacterial form of which is also known as lipopolysaccharide (LPS) - is found predominantly in the cell wall outer membrane of Gram-negative bacteria ${ }^{17}$, whereas lipoteichoic acid and peptidoglycan are found in the cell walls of Gram-positive bacteria. The polysaccharide $\beta-1,3$-glucan is not found in either group of bacteria, but only in the cell walls of fungi such as the baker's yeast, Saccharomyces cerevisiae.

LOCAD-PTS detects endotoxin and $\beta-1,3$-glucan with the Limulus amebocyte lysate (LAL) assay. The LAL assay is derived from early discoveries that microbial infection causes blood clots in the horseshoe crab Limulus polyphemus ${ }^{18}$ and that the causative agent is endotoxin ${ }^{19-21}$. In 1977, the LAL assay replaced the rabbit pyrogen test for endotoxin ${ }^{22}$ and in 1983, the Food and Drug Administration (FDA) certified the LAL assay as a standard test for endotoxins. 
The LAL assay is now used routinely to monitor endotoxin, as an important entity by itself and as a proxy for Gram-negative bacteria, in a wide range of products and applications. These include: dairy products ${ }^{23}$, eye surgery ${ }^{24}$, heart surgery ${ }^{25}$, dental surgery ${ }^{26}$, diagnosis of gram-negative peritonitis ${ }^{27}$, biofilms in dialysis systems ${ }^{28}$, organs for transplantation ${ }^{29}$, microbial contamination of metal-working fluids ${ }^{30}$, air monitoring in factories ${ }^{31}$, research of cyanobacterial blooms ${ }^{32}$, in plasmid-DNA based gene therapy to verify that gene vectors are endotoxinfree f3,34 $^{33}$.

While the LAL assay can be coupled to a turbidimetric reaction, this is time-consuming and laborintensive. To address this issue, the LAL assay was coupled to a colorimetric reaction (see Fig. 2) by Charles River Laboratories Inc. (Charleston, SC) to generate the Endosafe ${ }^{\mathrm{TM}}$ Portable Test System (PTS). The Endosafe PTS is a portable spectrophotometer coupled with a range of thumb-sized cartridges in which the colorimetric LAL reaction takes place. Each LALcontaining cartridge also contains p-nitroalanine, which is converted into a yellow/green product if endotoxin is present in the original sample.

Limulus Enzyme Cascade

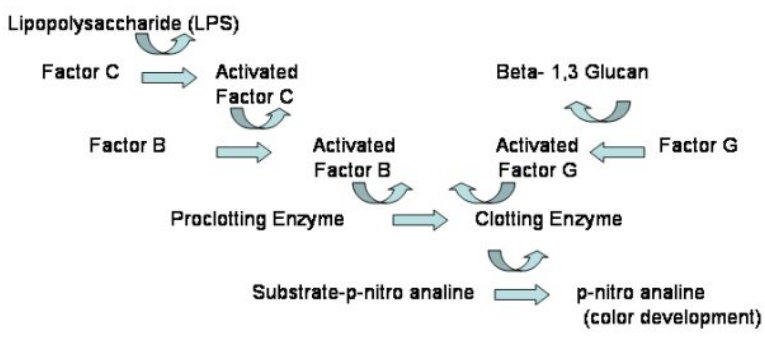

Figure 2. Colorimetric LAL cascade

The Endosafe ${ }^{\mathrm{TM}}$ PTS was then modified by the LOCAD Team at NASA Marshall Space Flight Center (MSFC) to deem it flight qualified, and ensure it could withstand the rigors of launch, and the space environment. The instrument, along with a novel sample collection device, became known as the LOCAD-PTS. LOCAD-PTS therefore consists of a modified Endosafe ${ }^{\mathrm{TM}} \mathrm{PTS}$, plus a surface sampling/processing kit that enables astronauts to collect surface samples, dilute them with endotoxin-free water, mix, and then dispense as a liquid into a LOCADPTS cartridge.

LOCAD-PTS was launched to the International Space Station (ISS) aboard Space Shuttle Discovery in December 2006 and remains onboard the ISS. This report describes preliminary results from eleven operations of LOCAD-PTS onboard the ISS from March 2007 until the spring of 2008.

This report describes LOCAD-PTS operations performed on the ISS to address five main objectives: i) Demonstrate correct instrument function in a mission environment (success criterion: mid/high reading for positive control); ii) Demonstrate crew handling of LOCAD-PTS supplies without biological contamination e.g. from skin (success criterion: $<0.05 \mathrm{EU} / \mathrm{ml}$ reading for negative control); iii) Demonstrate consistent and reliable crew operations of LOCAD-PTS in a mission environment; iv) Conduct general survey of surface endotoxin within Node 1 and the US Lab; and iv) Compare and contrast endotoxin data with colony forming unit (CFU) data obtained from adjacent areas at each site. 


\section{Hardware}

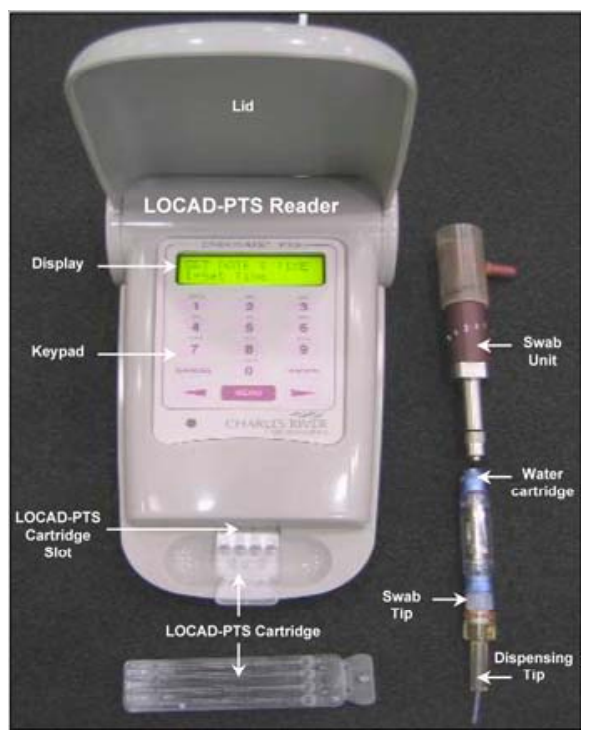

A. Reader

The LOCAD-PTS Reader is a handheld integrated spectrophotometer, heater, pump with built-in electronics and software to perform various assays with LOCAD-PTS Cartridges (see Fig. 3). Two Readers were chosen for space flight (one as back-up) and both were manufactured and modified for space flight by Charles River Laboratories. Modifications of the commercially available Readers were minor as far as assay function was concerned and included removal of the battery from the Reader to comply with ISS safety regulations.

\section{B. Cartridges}

LOCAD-PTS LAL cartridges (manufactured by CRL) were approximately $10 \mathrm{~cm}$ long, $3 \mathrm{~cm}$ wide and inserted into the Reader to perform each assay (see Fig. 4). Each cartridge was manufactured from polycarbonate plastic and consisted of four sample wells (each designed to receive $25 \mu \mathrm{l}$ of liquid sample), with each sample well connected to a

Figure 3. LOCAD-PTS

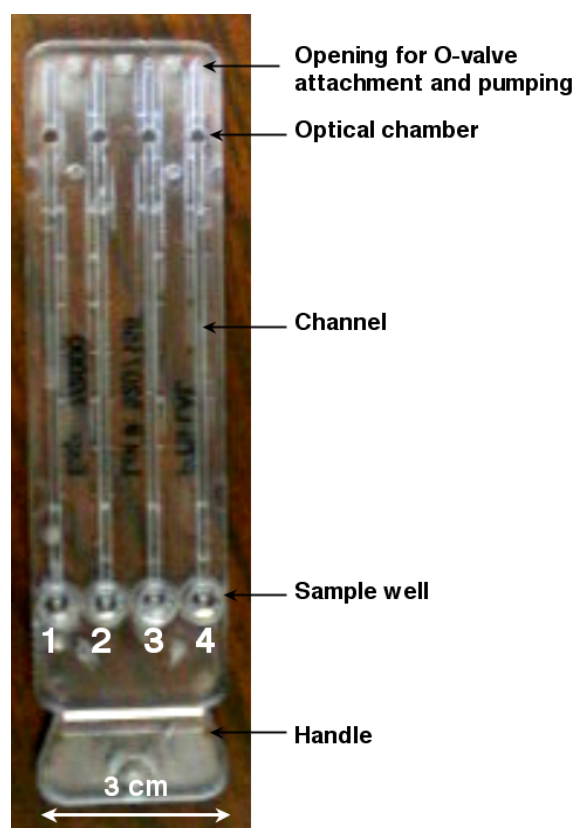

Figure 4. Cartridge channel that leads to an optical chamber. Beyond each of the four optical chambers is a small opening that interfaces with O-rings and a pump in the Reader. This pump was programmed by the Reader software to move fluid up and down the channels of the cartridge as required.

\section{Swabbing Unit}

The Swabbing Unit was designed and manufactured by the University of Huntsville in Alabama (UAH) (see Fig. 5). It consists of a hand-held pipette and swabbing device. Several notches were included on the swabbing unit, labeled (from the top): P, W, 1, 2, 3, 4, 5 and 6. Notch W was the largest notch and moving the knob up and down in this position enabled sample mixing. Notches 1-6 were of identical size and enabled dispensing of uniform $25 \mu$ droplets into the sample wells of LOCAD-PTS cartridges (see below for a more detailed description of these procedures). Two swabbing units were chosen to launch on STS-116 (one as a back-up).

\section{Swabbing Kits}

Each swabbing kit consisted of a water cartridge, swabbing tip and dispensing tip, and was designed and manufactured at NASA MSFC (see Fig. 6). Each swabbing kit consisted of three components: a water cartridge, a swab tip and a dispensing tip. The water cartridge was constructed with two Luer-lok valves at either end. The swabbing tip consisted of a polycarbonate Luerlok, covered with Dacron material to form a circular tip with a diameter of $8 \mathrm{~mm}$. The capacity of each dispensing tip was $150 \mu$ l. Each component of the swabbing kit was cleaned to remove endotoxin by boiling in $6 \%$

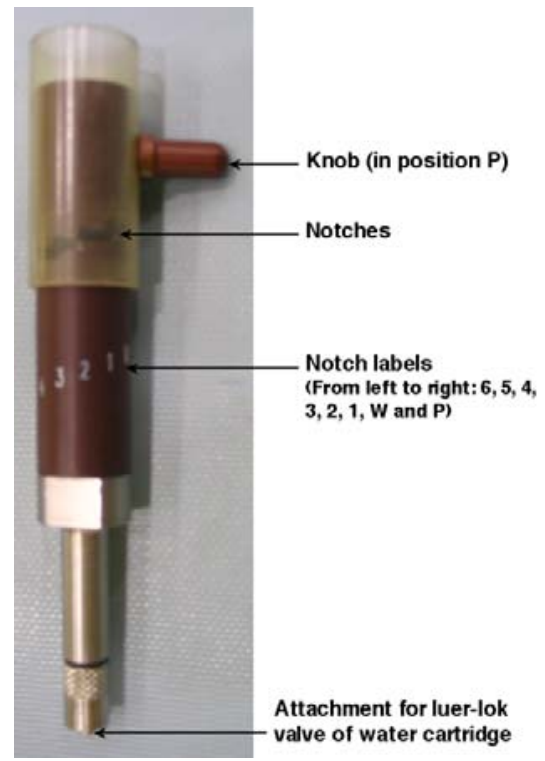

Figure 5. Swabbing Unit

American Institute of Aeronautics and Astronautics 092407 
hydrogen peroxide for at least 20 minutes. The components and Teflon-980 material were then dried in a clean, sterile, laminar flow hood. After drying, water cartridges were filled with endotoxin-free water (LAL reagent water, LRW, product number W110; CRL, Charleston, SC) under a laminar flow hood. The swabbing kits were then packaged to include: one full water cartridge, one swabbing tip and one dispensing tip. To ascertain cleanliness of these swabbing kits, 5 out of every 100 produced were analyzed with LOCADPTS on the ground before launch. A total of 84 swabbing kits were launched on Space Shuttle STS-116.

\section{E. Media “Contact” slides.}

This investigation used the term 'media slides' interchangeably to refer to the 'contact slides' manufactured by Biotest USA (Denville, NJ). Media slides consisted of microbial growth media in the form of a solid gel rectangular pad, supported by a plastic (PVC) tray (see Fig. 7 A and B). This media slide was stored in sealed plastic container until use. When required, the container was pealed open (see Fig. 7, C), the media slide removed (see Fig. 7, D) and applied to a surface of interest (see Fig. 7, E). Following surface application, the media slide was returned to the container, which was secured with a plastic

cover seal (see Fig. 7 B).

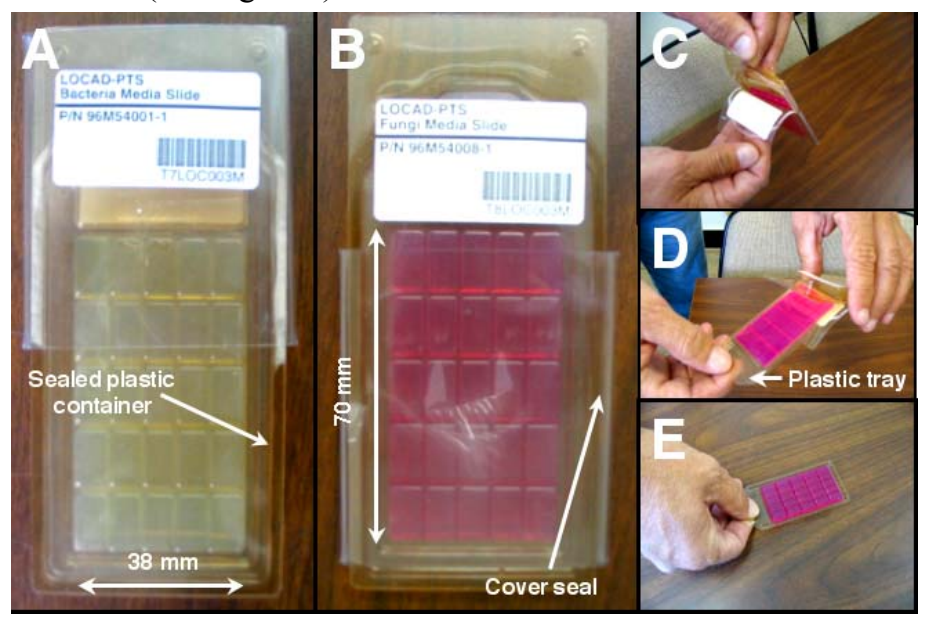

Figure 7. Media 'Contact' Slides

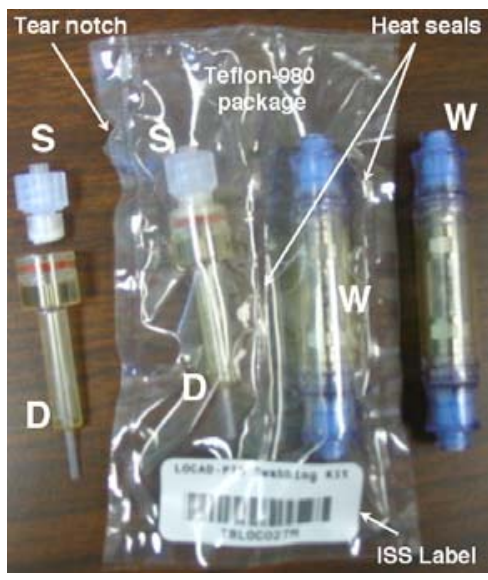

Figure 6. Swabbing Kit

Two types of media slide were used in this investigation and referred to as 'Bacteria' and 'Fungi' media slides. Bacteria media slides corresponded to and were identical to the TC contact slides from Biotest and consisted of tryptic soy agar (product number 931250100 , Biotest USA). Fungi media slides corresponded to and were identical to YM contact slides and consisted of Rose Bengal Agar with gentamicin sulphate (product number 931280 100, Biotest USA). The surface area of each media slide was $25 \mathrm{~cm}^{2}$ (to meet International Regulations USP24 and EP3).

\section{Procedures}

\section{A. Crew Training}

In general, crewmembers were trained in LOCAD-PTS operations approximately 12-18 months before launch. In this experiment, procedures onboard ISS were performed by crewmember Sunita Williams, Peggy Whitson, Dan Tani and Greg Chamitoff. Each received a 1-hour training session in the mock-up ISS U.S. Laboratory facility at NASA Johnson Space Center (Houston, TX) several months preceding their mission. In addition, some crewmembers attended a 2-day training session in molecular biology at the Marine Biological Lab (Woods Hole, MA) during 2004, where they were familiarized with LOCAD-PTS. In the JSC training session, Williams was trained to perform a complete end-to-end analysis of a surface swab with LOCAD-PTS, with special attention paid to operation of the swabbing unit to perform mixing and dispensing operations.

\section{B. Shipping and pre-launch}

All LOCAD-PTS equipment was packaged by Teledyne Brown Engineering (TBE) at MSFC into a Half Cargo Transfer Bag (CTB). The 'Half' refers to middeck locker equivalents (MLEs) i.e. a Half CTB will fill half of a Space Shuttle middeck locker. A Half-CTB has a 30 pounds maximum carrying capacity, with the dimensions of 
16.75 by 9.75 by 9.25 inches. In order to support and protect equipment against vibrations and shock during ground transport and launch, major components (such as the two Readers) were separated by a solid foam material.

\section{Launch and transfer to ISS}

LOCAD-PTS was launched aboard Space Shuttle Discovery (STS-116) on December $9^{\text {th }} 2006$, which docked with the ISS on December $12^{\text {th }} 2006$. Following docking, the half-CTB containing LOCAD-PTS was transferred to the US Lab of the ISS, and stowed at ambient pressure (15 psi) and temperature $\left(76^{\circ} \mathrm{F}\right)$ until use on March $31^{\text {st }}$ 2007.

\section{Overview of ISS Operations}

Each operating session was defined as either a 'Phase 1' session or 'Phase 2' session. Each Phase 1 session was performed according to the surface sampling layout in Fig. 8, with four surface swabs performed around two centrally placed media slides (for the culture-based detection of fungi and bacteria). Each of these four swabs was analyzed with LOCADPTS, so that data from LOCAD-PTS culture-based methods were obtained for each site. The duration of a typical phase 1 session was approximately 3 hours. Each Phase 2 session consisted of five individual surface swabs of separate sites within the ISS; these sessions were slightly shorter than Phase 1 sessions, running approximately 2-3 hours. The selection of these sites were sometimes guided by the LOCAD-PTS operations team, but often left to crew discretion. These Phase 2 sessions constituted an exploratory survey of surface endotoxin throughout the ISS.

A total of five Phase 1 sessions and five Phase 2 sessions were performed for LOCAD-PTS LAL analysis of surface endotoxin. Each Phase 1 session was performed by astronaut Suni Williams on March $31^{\text {st }}$,

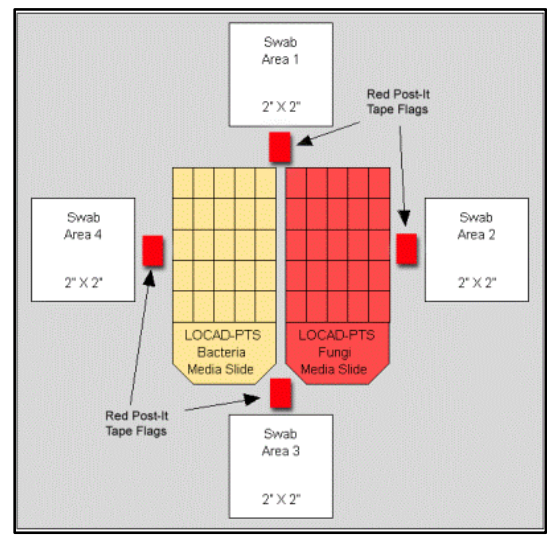

Figure 8. Surface sampling layout April 30th, May $5^{\text {th }}$, May $8^{\text {th }}$ and May $15^{\text {th }}, 2007$. The surface sites chosen for each of these five sessions are shown in Fig. 9. Each of the Phase 2 LAL sessions were performed by astronauts Peggy Whitson and Dan Tani on December $20^{\text {th }}, 21^{\text {st }}$ and $24^{\text {th }} 2007$ and February $2^{\text {nd }} 2008$. Phase 1 Glucan sessions began on June $21^{\text {st }} 2008$, performed by astronaut Greg Chamitoff.

The LOCAD-PTS operations team supported each session from mission control at the Payload Operations Integration Center (POIC) at MSFC. Prior to each astronaut's first session, a science conference was scheduled so that the crew could discuss procedures and scientific objectives with the LOCAD-PTS team. Prior to on-orbit operations, all crew procedures were tested first by the LOCAD-PTS operations team in the microgravity environment of parabolic flight (Maule et al., 2004).

\section{E. Swabbing}

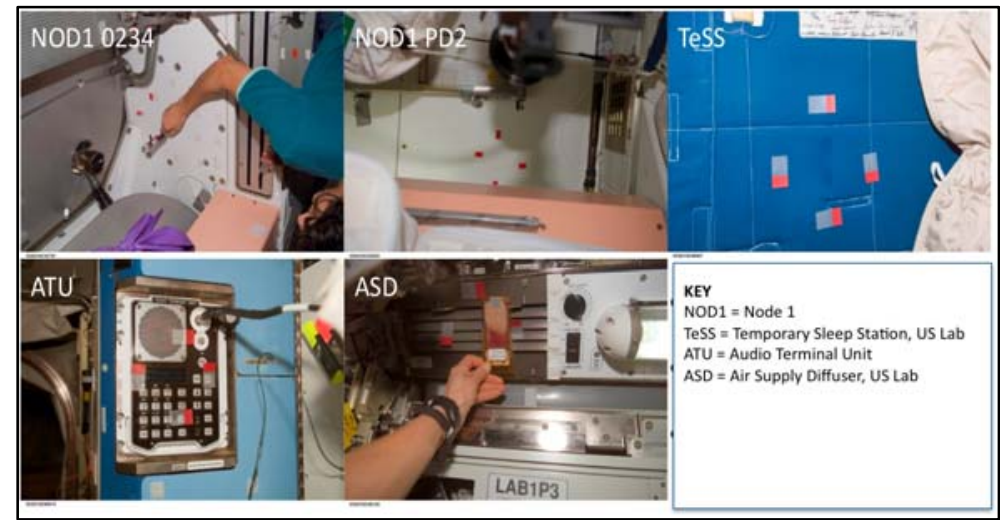

Figure 9. Surface site locations during Phase 1 LAL operations

As can be seen from Fig. 8, each LOCAD-PTS swab covered a surface area of $25 \mathrm{~cm}^{2}$ (or 2" x 2"), with all four swabs surrounding two centrally placed contact slides (for the culture-based detection of bacteria and fungi) during Phase 1. Swabs performed during Phase 2 similarly covered $25 \mathrm{~cm}^{2}$ (but contact media slides were not used in Phase 2 ). In this way, both culture-independent and culture-based methods were used together to analyze an approximate 10 " x 10" area (i.e., the grey box in Fig. 8). The crew prepared to swab in this layout by placing four red post-it flags on the surface site (see red rectangles in Fig. 8); applying contact slides within those four post-it flags; followed by four swabs at the positions indicated. The swabbing protocol began with direct attachment of the water cartridge of the swabbing kit via a push-and-turn action (while the knob of the swabbing unit was at position P). The water cartridge was then attached to the swabbing tip by another push-and-turn action. At this point the swab unit was in 
the 'swabbing configuration' i.e., a surface sample could be obtained by swabbing a surface with the swabbing tip (see Fig. 10).

\section{F. Mixing}

Following swabbing, the dispensing tip was attached to the swab tip via a push-on O-ring seal. This is called the 'mixing/dispensing configuration' and at this point, mixing and dispensing took place. The knob on the swabbing unit was manipulated up and down in notch W (see Fig. 5) five times at a rate of once per 2 seconds to mix the swab sample with $1.2 \mathrm{ml}$ of endotoxin-free water in the water cartridge. Following mixing, the crew performed the dispensing procedure (see below).

\section{G. Dispensing}

Following mixing, the knob of the swabbing unit was left in position 1. A further droplet was dispensed, and then droplets were dispensed into an inserted LOCAD-PTS cartridge by cycling through notches 2-6. Moving the knob down each of the subsequent notches (labeled 1-6) dispensed droplets of approximately $25 \mu$ l each. Fig. 11 shows Suni Williams dispensing a sample onboard the ISS during Phase 1 LAL operations.

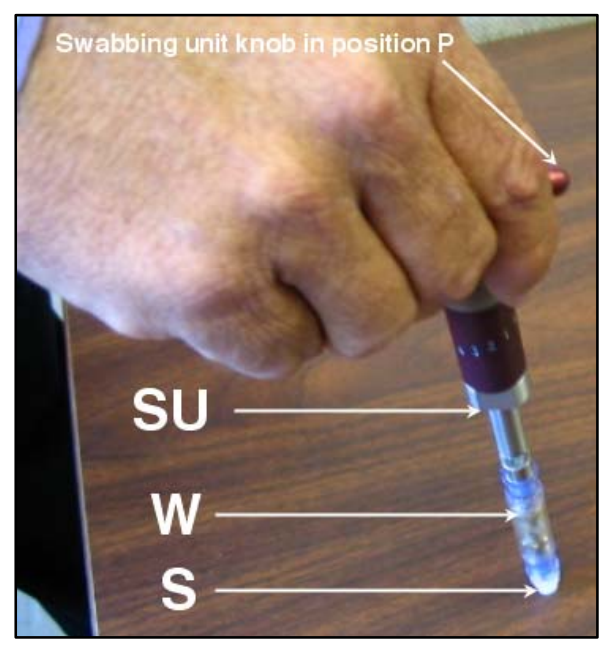

Figure 10. Swabbing configuration. SU = swab unit; $\mathbf{W}$ = water cartridge; $\mathrm{S}=$ swab tip

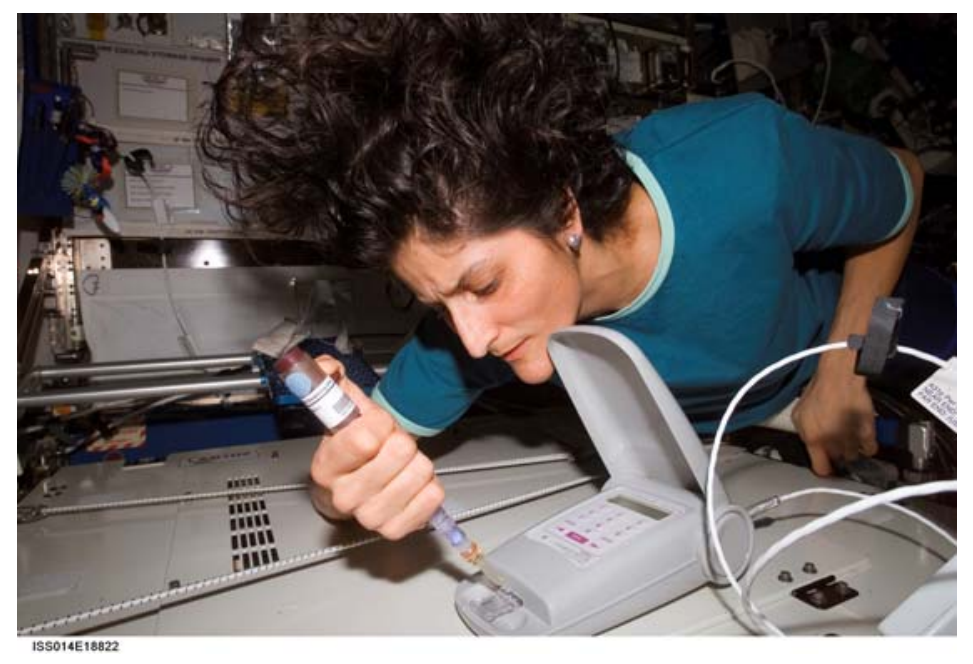

Figure 11. Astronaut Suni Williams dispensing a mixed surface sample during Phase 1 LAL operations (March, 2007)

\section{Discussion}

This report describes the operation of a new type of biochemical microbial analysis performed aboard the International Space Station (ISS) that builds upon the collective experience and excellent previous studies performed in both the United States and Russia, from the early programs of Apollo ${ }^{4,5}$ and Salyut ${ }^{13}$, to space station Mir ${ }^{10-12}$, the Shuttle-Mir program ${ }^{3}$ and most recently, the ISS $^{2,6-9}$.

It was the first demonstration of complete biochemical analysis of environmental samples onboard a space station from sampling to onboard data. While the analytical test performed was relatively simple - the Limulus Amebocyte Lysate (LAL) assay for detection of endotoxin and $\beta-1,3$-glucan - the demonstration of the technology and procedures serves as a foundation for future generations of more specific tests. The ease with which a variety of crewmembers - pilots and scientists - performed procedures was especially important, given that a relatively high level of hand-eye coordination and control was required, especially for the dispensing phase of operations. While this procedure might be second nature to a biochemist, it may not so familiar to others, especially in a microgravity environment; however, all crewmembers performed procedures equally well throughout each session.

A potential concern prior to this study was the absence of gloves from crew procedures, which could lead to skin-derived biological contamination of the swab tip and false positive readings. The negative control was designed to address this concern (where procedures were performed without a surface swab). No positive readings were obtained during any of the three negative controls performed on orbit - indicating that procedures did not introduce contamination to the swab tip (and that the reagents remained clean following extended storage on orbit). 
The waived requirement for gloves is a major advantage given the extra up-mass of clean gloves (and onboard storage requirements), down-mass of used gloves, and greater crew time required for gloved operations. The robust design of the cartridges, which enabled handling with bare hands, was a major benefit to operations within the distinctly non-sterile ISS cabin environment.

While there is no general correlation between data endotoxin or $\beta-1,3$-glucan levels and $\mathrm{CFU}$, the two types of data can be used together to generate a more complete story of microbial ecology on the ISS. This approach has been implemented im other research areas, from hygiene monitoring on Earth ${ }^{35}$ to studies of extreme environments on Earth, such as Kamchatka ${ }^{36}$ and the Arctic ${ }^{37}$. Onboard culture-independent analysis shall become increasingly important following the planned retirement of the Space Shuttle in 2010 (with limited up/down mass for culturebased systems) and during Constellation missions beyond low Earth orbit. In response to these events, we shall present a set of new microbial monitoring requirements based upon culture-independent parameters measured by LOCAD-PTS.

\section{Acknowledgments}

Many thanks to astronauts Suni Williams, Peggy Whitson, Dan Tani and Greg Chamitoff, who operated LOCADPTS on the ISS; LOCAD Team Payload Integration Managers Lorrie Hellier and Jeff Durham for their hard work preparing LOCAD-PTS for launch and during operations; ISS Program Scientist Julie Robinson, Increment Scientists Vic Cooley and Kenol Jules, NASA Johnson Space Center (JSC), for facilitating science sessions within the constraints of ISS mission operations; Duane Pierson, Mark Ott, Victoria Castro, Willy Wong, Anthony Jeevarajan and Bekki Bruce, Microbiology Group, NASA JSC, and Jeff Jones, Flight Surgeon, NASA JSC, for their support in the transition of LOCAD-PTS to a spaceflight instrument.

\section{References}

${ }^{1}$ Fox, L., "The ecology of micro-organisms in a closed environment." Life Sci Space Res. 1971; 9: 69-74.

${ }^{2}$ Castro, V.A., Thrasher, A.N., Healy, M., Ott, C.M., Pierson, D.L., "Microbial characterization during the early habitation of the International Space Station." Microb. Ecol. 2004 Feb; 47(2): 119-26.

${ }^{3}$ Pierson, D.L., "Microbial contamination of spacecraft." Gravit. Space Biol. Bull 2001; 14(2):1-6.

${ }^{4}$ Puleo, J.R., Oxborrow, G.S., Fields, N.D., Herring, C.M., Smith, L.S., "Microbiological profiles of four Apollo spacecraft." Appl Microbiol. 1973 Dec; 26(6): 838-45.

${ }^{5}$ Puleo, J.R., Oxborrow, G.S., Fields, N.D., Hall, H.E., "Quantitative and qualitative microbiological profiles of the Apollo 10 and 11 spacecraft." Appl Microbiol. 1970 Sep; 20(3): 384-9.

${ }^{6}$ Novikova, N., De Boever, P., Poddubko, S., Deshevaya, E., Polikarpov, N., Rakova, N., Coninx, I., Mergeay, M., "Survey of environmental biocontamination onboard the International Space Station." Res Microbiol. 2006 Jan-Feb; 157(1): 5-12.

${ }^{7}$ Novikova, N.D., "Review of the knowledge of microbial contamination of the Russian manned spacecraft." Microb Ecol. $2004 \mathrm{Feb} ; 47(2): 127-32$.

${ }^{8}$ Novikova, N.D., "Basic patterns of microflora development in the environment of orbital complex Mir." Aviakosm Ekolog Med. 2001; 35(4):32-40.

${ }^{9}$ Rakova, N.M., Svistunova, I.V., Novikova, N.D., "Studies on the growth and reproduction of bacterial communities on structural materials of the international space station." Aviakosm Ekolog Med. 2005 Jan-Feb; 39(1): 44-6.

${ }^{10}$ Viktorov, A.N., Novikova, N.D., Deshevaia, E.A., Bragina, M.P., Shnyreva, A.V., Sizova, T.P., D'iakov, I.T., "Residential colonization of orbital complex "Mir" environment by penicillium chrysogenum and problem of ecological safety in long-term space flight". Aviakosm Ekolog Med. 1998;32(5):57-62.

${ }^{11}$ Viktorov, A.N., Novikova, N.D., Deshevaia, E.A., "The cabin microflora of manned space vehicles and the problem of the biological destruction of the construction materials used in them." Aviakosm Ekolog Med. 1992 May-Jun; 26(3): 41-8.

${ }^{12}$ Shikina, M.I., Vinogradova, L.A., Kolesina, N.B., "Microflora of the drinking water regenerated from atmospheric moisture condensate in hermetically sealed quarters." Kosm Biol Aviakosm Med. 1988 Mar-Apr; 22(2): 53-6.

${ }^{13}$ Nefedov, Y.G., Shilov, V.M., Konstantinova, I.V., Zaloguyev, S.N., "Microbiological and immunological aspects of extended manned space flights." Life Sci Space Res. 1971; 9:11-6.

${ }^{14}$ Keep, N.H., Ward, J.M., Robertson, G., Cohen-Gonsaud M., Henderson, B., "Bacterial resuscitation factors: revival of viable but non-culturable bacteria". Cell Mol Life Sci. 2006 Nov; 63(22): 2555-9.

${ }^{15}$ Byrd, J.J., Xu, H.S., Colwell, R.R., "Viable but nonculturable bacteria in drinking water." Appl. Environ. Microbiol. 1991 Mar; 57(3): 875-8.

${ }^{16}$ Gram, H.C., "Über die isolierte Färbung der Schizomyceten in Schnitt- und Trockenpräparaten". Fortschritte der Medizin, 1884; 2: 185-89.

${ }^{17}$ Tefsen, B., Geurtsen, J., Beckers, F., Tommassen, J., de Cock, H., "Lipopolysaccharide transport to the bacterial outer membrane in spheroplasts." J. Biol. Chem. 2005, Feb 11; 280(6):4504-9.

${ }^{18}$ Bang, F.B., “A bacterial disease of Limulus polyphemus.” Bull Johns Hopkins Hosp.1956 May;98(5):325-51.

${ }^{19}$ Levin, J., and Bang, F.B., "Clottable protein in Limulus; its localization and kinetics of its coagulation by endotoxin”..Thromb. Diath. Haemorrh.. 1968 Mar 31;19(1):186-97. 
${ }^{20}$ Levin, J., and Bang, F.B., “A description of cellular coagulation in the Limulus.” Bull Johns Hopkins Hosp. 1964 Oct;115: $337-45$.

${ }^{21}$ Levin, J., and Bang, F.B., "The role of endotoxin in the extracellular coagulation of Limulus blood." Bull Johns Hopkins Hosp. 1964 Sep;115: 265-74.

${ }^{22}$ Ronneberger, H.J., "Comparison of the pyrogen tests in rabbits and with limulus lysate." Dev Biol Stand. 1977;34: 27-36.

${ }^{23}$ Mottar, J., De Block, J., Merchiers, M., Vantomme, K., Moermans, R., "Routine limulus amoebocyte lysate (LAL) test for endotoxin determination in milk using a Toxinometer ET-201." J. Dairy Res. 1993 May; 60(2): 223-8.

${ }^{24}$ Spelsberg, H., Reinhard, T., Sokolovska, Y., Zysk, G., Böhringer, D., Sundmacher, R., "Endotoxin in storage medium of human corneal grafts and clinical course after penetrating normal-risk keratoplasty." Eye. 2004 Sep; 18(9):923-8.

${ }^{25}$ Bowles, C.T., Ohri, S.K., Klangsuk, N., Keogh, B.E., Yacoub, M.H. and Taylor, K.M., "Endotoxaemia detected during cardiopulmonary bypass with a modified Limulus amoebocyte lysate assay." Perfusion. 1995 Jul; 10(4): 219-28.

${ }^{26}$ Martinho, F.C. and Gomes, BP., "Quantification of endotoxins and cultivable bacteria in root canal infection before and after chemomechanical preparation with 2.5\% sodium hypochlorite." J. Endod. 2008 Mar; 34(3): 268-72.

${ }^{27}$ Pee, G., Serban, I., Blum, M., Cabili, S. and Iaina, A., "Early diagnosis of gram-negative peritonitis in continuous ambulatory peritoneal dialysis patients with the Lymulus amebocyte lysate assay." Am. J. Nephrol. 1992; 12(1-2):19-21.

${ }^{28} \mathrm{Liu}, \mathrm{H}$., Li, G., Zhang, X., Duan, X., Yao, Y., "A study on the endotoxin and bacterial contamination in reverse osmosis water and dialysis fluids." Zhonghua Nei Ke Za Zhi. 1999 Dec; 38(12): 806-9.

${ }^{29}$ Pillay, S.P., Wynter, C., Lynch, S., Wall, D., Balderson, G., Strong, R., "Endotoxin levels in donors and recipients during orthotopic liver transplantation.” Aust N Z J Surg. 1997 Apr; 67(4): 187-91.

${ }^{30}$ Cyprowski, M., Piotrowska, M., Zakowska, Z, Szadkowska-Stańczyk, I., "Microbial and endotoxin contamination of watersoluble metalworking fluids.".Int J Occup Med Environ Health. 2007; 20(4): 365-71.

${ }^{31}$ Marchand, G., Lalonde, M., Beaudet, Y., Boivin, G., Villeneuve, S., Pépin, C., "Documentation of the endotoxins present in the ambient air of cotton fiber textile mills in Québec." J. Environ. Monit. 2007 Aug; 9(8): 869-76.

${ }^{32}$ Bernardová, K., Babica, P., Marsálek, B. and Bláha, L.J., "Isolation and endotoxin activities of lipopolysaccharides from cyanobacterial cultures and complex water blooms and comparison with the effects of heterotrophic bacteria and green alga." Appl Toxicol. 2008 Jan; 28(1): 72-7.

${ }^{33}$ Wells, D.J., Maule, J., McMahon, J., Mitchell, R., Damien, E., Poole, A., Wells, K.E., "Evaluation of plasmid DNA for in vivo gene therapy: factors affecting the number of transfected fibers.” J Pharm Sci. 1998 Jun; 87(6):763-8.

${ }^{34}$ Wells, K.E., Maule, J., Kingston, R., Foster, K., McMahon, J., Damien, E., Poole, A., Wells, D.J., "Immune responses, not promoter inactivation, are responsible for decreased long-term expression following plasmid gene transfer into skeletal muscle." FEBS Lett. 1997 Apr 28; 407(2):164-8.

${ }^{35}$ Aycicek, H., Oguz, U., Karci, K., “Comparison of results of ATP bioluminescence and traditional hygiene swabbing methods for the determination of surface cleanliness at a hospital kitchen." Int. J. Hyg Environ. Health. 2006 Mar; 209(2): 203-6.

${ }^{36}$ Maule, J., Morrill, P., Shaw, A. and Leuko, S., "International 2006 NAI Expedition to Kamchatka". NASA Astrobiology Conference, Santa Clara, CA. April 2008.

${ }^{37}$ Steele, A., Amundsen, H.E.F., Conrad, P.G., Benning, L., and Fogel, M., on Behalf of the AMASE 07 team, "Arctic Mars Analogue Svalbard Expedition (AMASE) 2007”. Lunar and Planetary Science Conference XXXIX (2008), Houston, TX. 


\section{Rapid Monitoring of Bacteria and Fungi aboard the International Space Station (ISS)}

47th AIAA Aerospace Sciences Meeting, Orlando, Florida. 5 - 8 Jan 2009. Session Title: ISS Research Results II (169-GPSE-4). Date: 07-Jan-09 (AM)

J. Maule and $\mathbf{N}$. Wainwright

British Aerospace (BAE) Systems, Huntsville, AL, 35806; and

Charles River Laboratories, Charleston, SC 29407

A. Steele

Geophysical Laboratory, Carnegie Institution for Science, Washington, DC, 20015

D. Gunter, G. Flores and M. Effinger

NASA MSFC, Huntsville, AL 35812

M. Damon and M. Wells

British Aerospace (BAE) Systems, Huntsville, AL, 35806; and

University of Alabama at Huntsville (UAH), Huntsville AL 35806

S. Williams

Astronaut Office, NASA Johnson Space Center, Houston, TX, 77058

H. Morris and L. Monaco

Jacobs Technology Inc., Huntsville, AL 35806 


\section{Summary}

1. Rationale

2. Current requirements

3. Existing in-flight methods to verify requirements

4. LOCAD-PTS: A new method to test for bacteria and fungi

- Hardware \& Biochemistry

- $\quad$ Launched 12/2006; operated since 3/2007

- $\quad$ Flight Schedule \& Operations Plan

- Objectives

- Procedures

- Results

- Conclusions

5. Proposed supplementary requirements 


\section{Rationale: Why monitor bacteria and fungi during human space flight?}

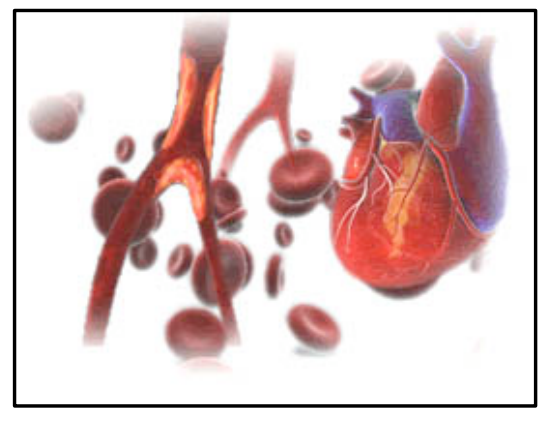

\section{Protect Crew Health}

- Short and Long-duration

- $\quad$ Primarily bacteria in drinking water; endotoxin within injectables

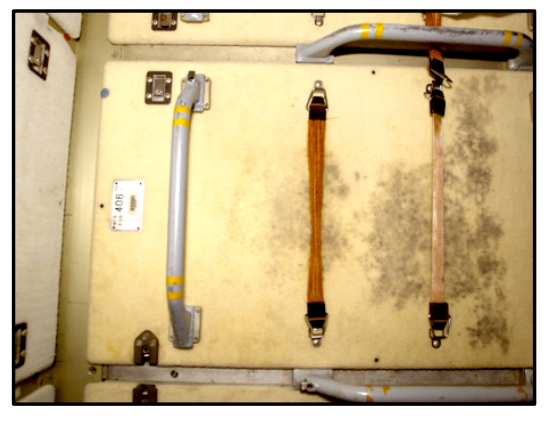

2. Protect Spacecraft Hardware

- $\quad$ Long-duration only

- $\quad$ Primarily fungi on surfaces

- $\quad$ Especially in areas inaccessible to cleaning

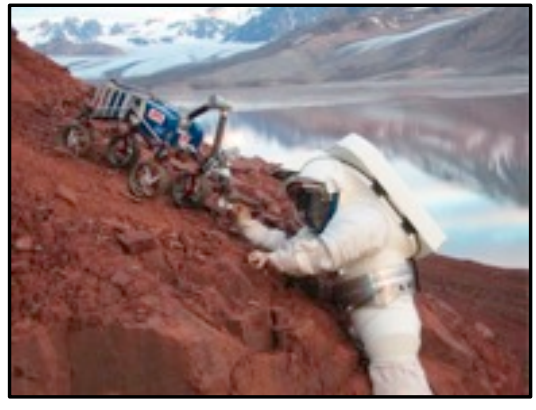

3. Protect Future Science and Planetary Protection

- During Constellation missions to Moon and Mars

- Initial short-duration stays and later long-duration stays

- Precedent: Apollo 7 - 14 (Puleo et al., 1973, 1970)

- $\quad$ Airlock and external surfaces (Maule et al., 2005 - 2008) 


\section{Current ISS Requirements}

Bacteria and Fungi on Internal Cabin Surfaces

\section{Defined in Colony Forming Units (CFU):}

- Requires culture of samples in growth media

- Number of colonies on solid media

- Measures bacterial/fungal viable numbers

- Detected on ISS surfaces in-flight using Contact Slides

\begin{tabular}{|c|c|c|}
\hline Flight Stage & Bacteria (CFU per 100 $\left.\mathrm{cm}^{2}\right)$ & Fungi $\left(\right.$ CFU per $\left.100 \mathrm{~cm}^{2}\right)$ \\
\hline Pre-flight & $<500$ & $<10$ \\
\hline In-flight & $<10,000$ & $<100$ \\
\hline
\end{tabular}




\section{Existing method: Surface Sampler Kit (SSK) \\ To verify current ISS surface requirements}

- Part of Crew Health Care System (CHeCS)

- "Two SSKs are on board the ISS at all times. Each SSK contains consumables for a 45-day period, so every $\mathbf{9 0}$ days the two kits on board are replaced with two new kits." [1]

- "Provides hardware for taking surface samples from ten locations". [1]

- Bacteria detected up to 4000 CFU per $100 \mathrm{~cm}^{2}$; fungi up to $400 \mathrm{CFU}$ per $100 \mathrm{~cm}^{2 \prime \prime}$

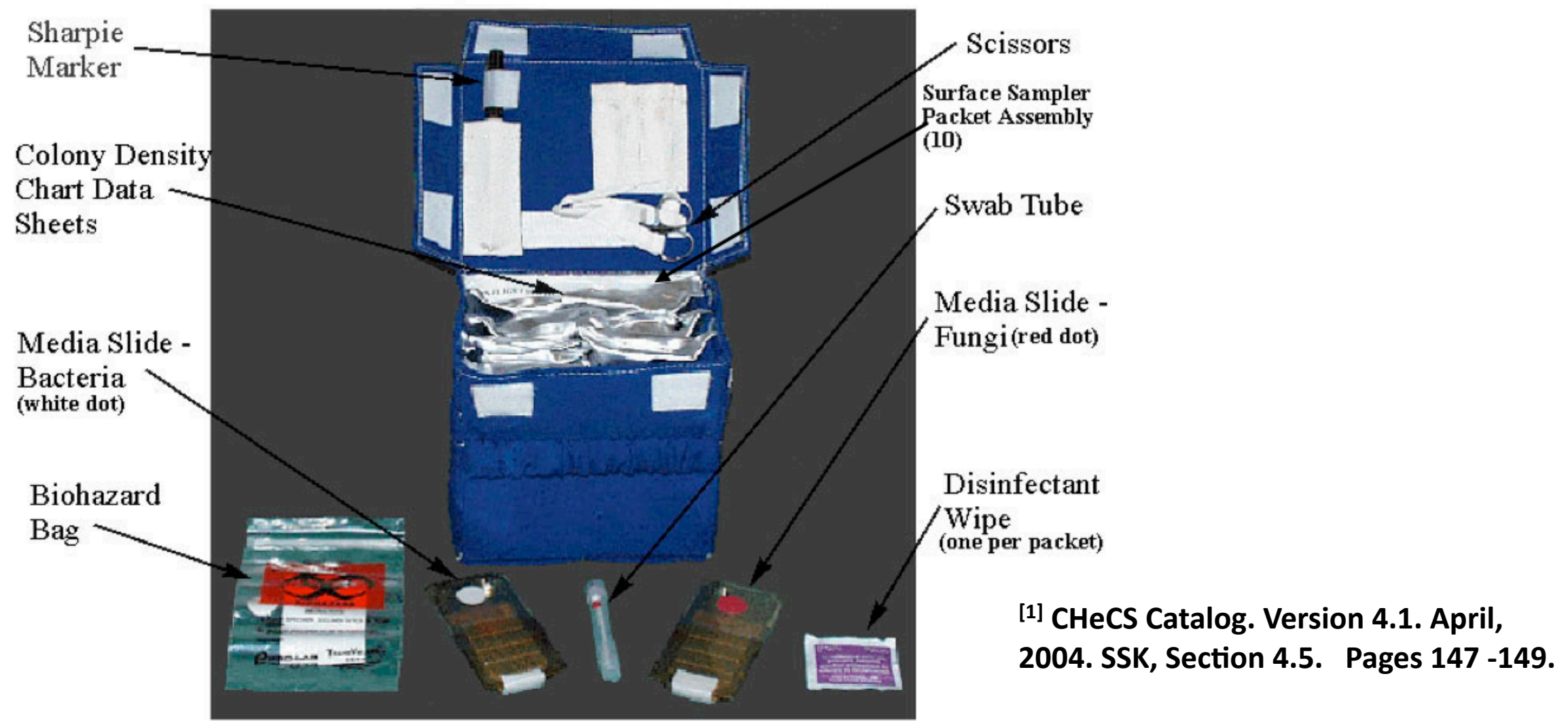




\section{Media / Contact Slides}

\section{To verify current ISS surface requirements}

- Agar-based gel growth media

- Applied to contact a surface, incubated for 3-5 days

- Photographed and assessed on a $\mathbf{1 - 5}$ scale

- Benefit: Targets only viable cells (relevant to crew health)

- Benefit: Detects up to $200 \mathrm{CFU}$ per $100 \mathrm{~cm}^{2}$ (more stringent than requirements)
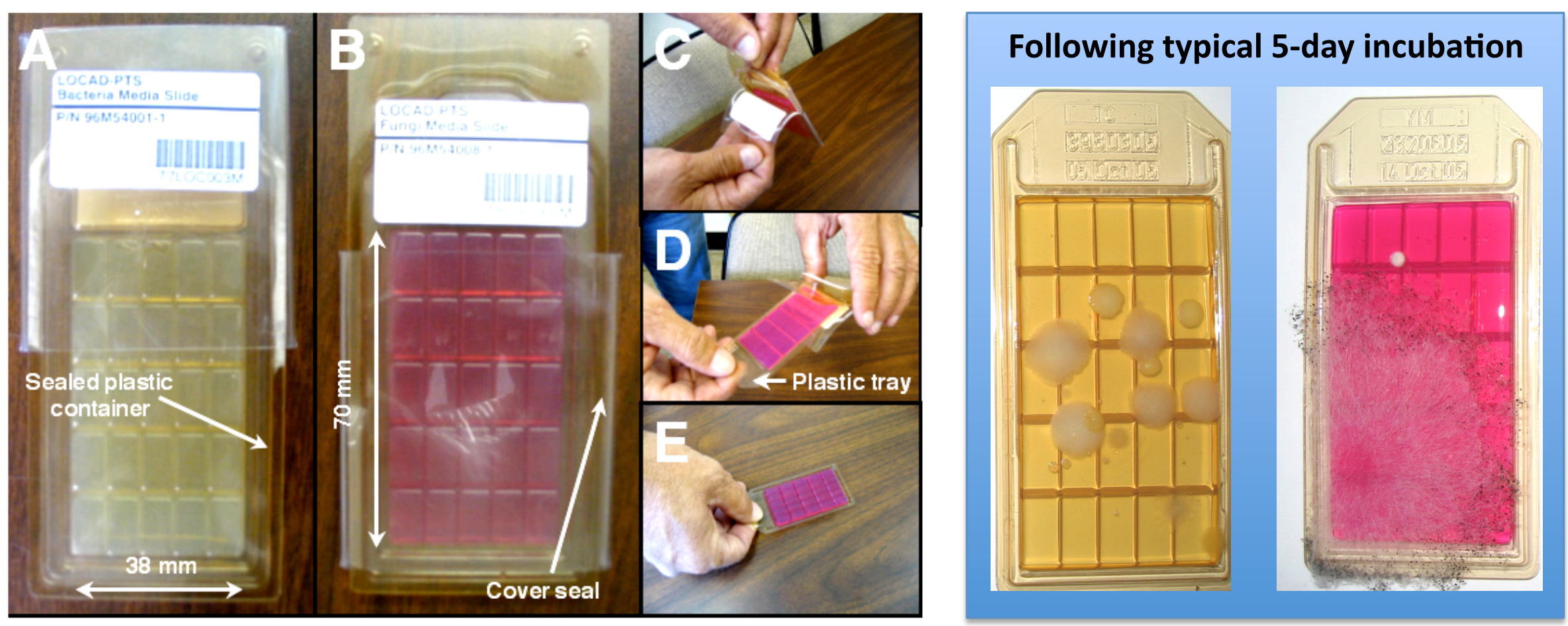


\section{SSK and Contact Slides: Limitations}

Rationale for a supplemental culture-independent system

- SSK analyzes "up to $\mathbf{4 0 0 0}$ CFU per $100 \mathrm{~cm}^{2}$ for bacteria"; contact slides up to $200 \mathrm{CFU}$ per $100 \mathrm{~cm}^{2}$. In-flight requirement is $<10,000 \mathrm{CFU}$ per $100 \mathrm{~cm}^{2}$.

- Lengthy analysis (several days).

- Does not detect microbes in Viable But Non-Culturable (VBNC) state: Many microorganisms in VBNC state retain toxicity (e.g., Baffone, 2003).

- Sample return is required for more extensive, molecular analysis

- Potential growth of harmful microorganisms: Which then require disposal.

- Difficulty observing colonies: Merging, Condensation, Flash photography...
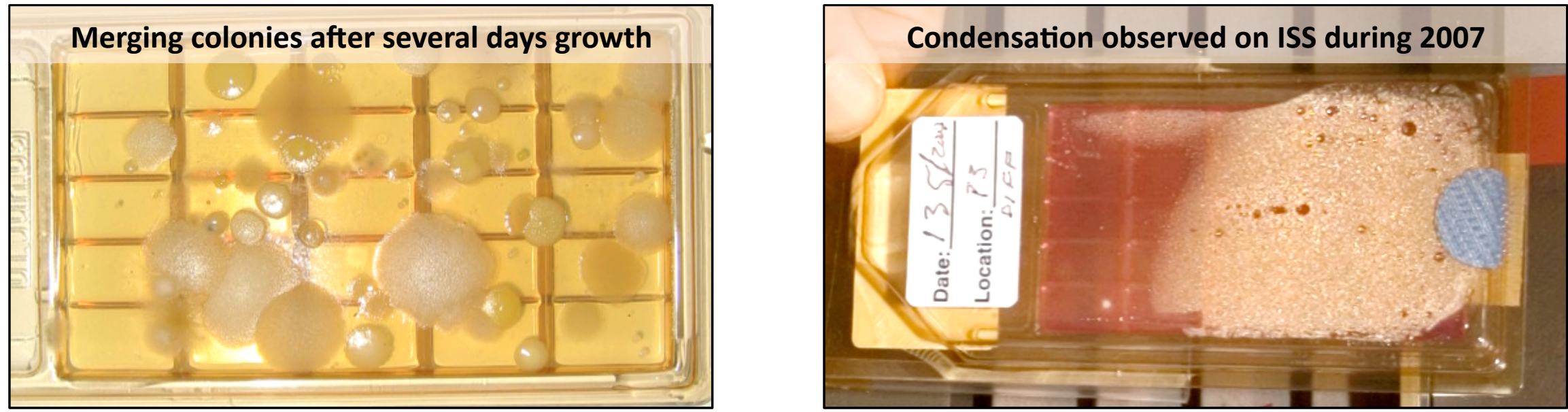


\section{LOCAD-PTS Hardware: Reader and Cartridge}
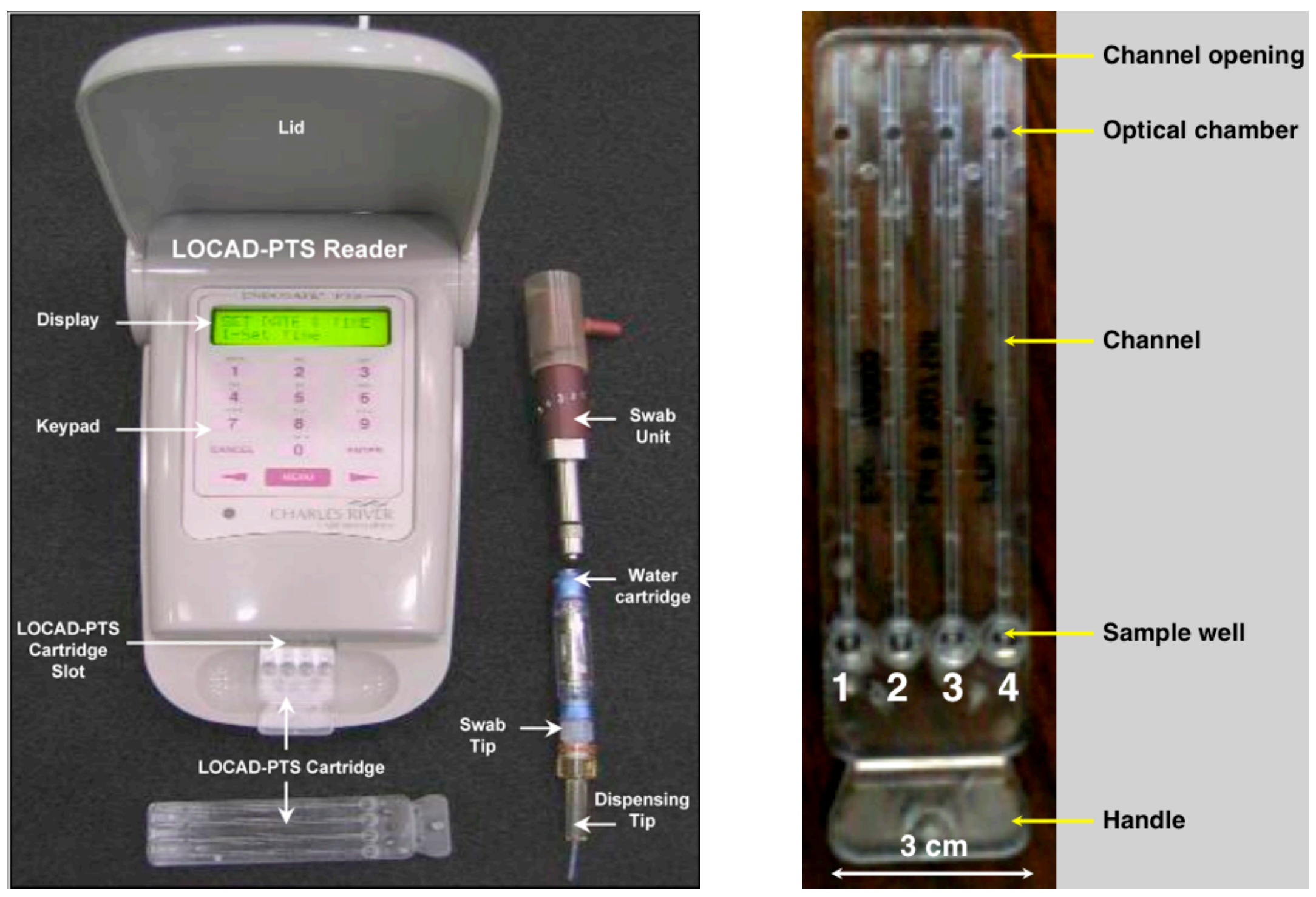


\section{LOCAD-PTS Hardware: Swab System}

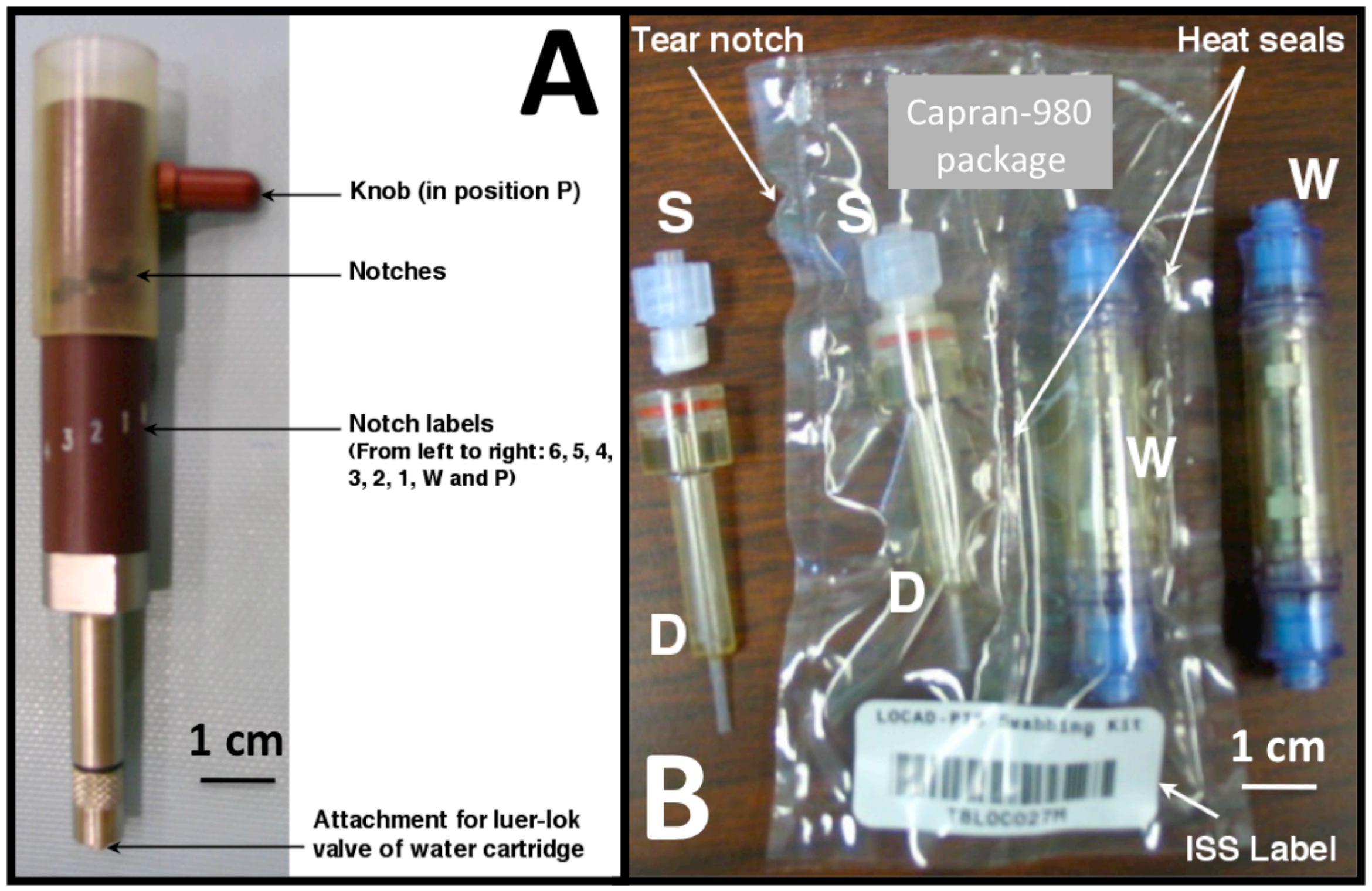




\section{LOCAD-PTS Biochemistry}

Gram-negative bacteria
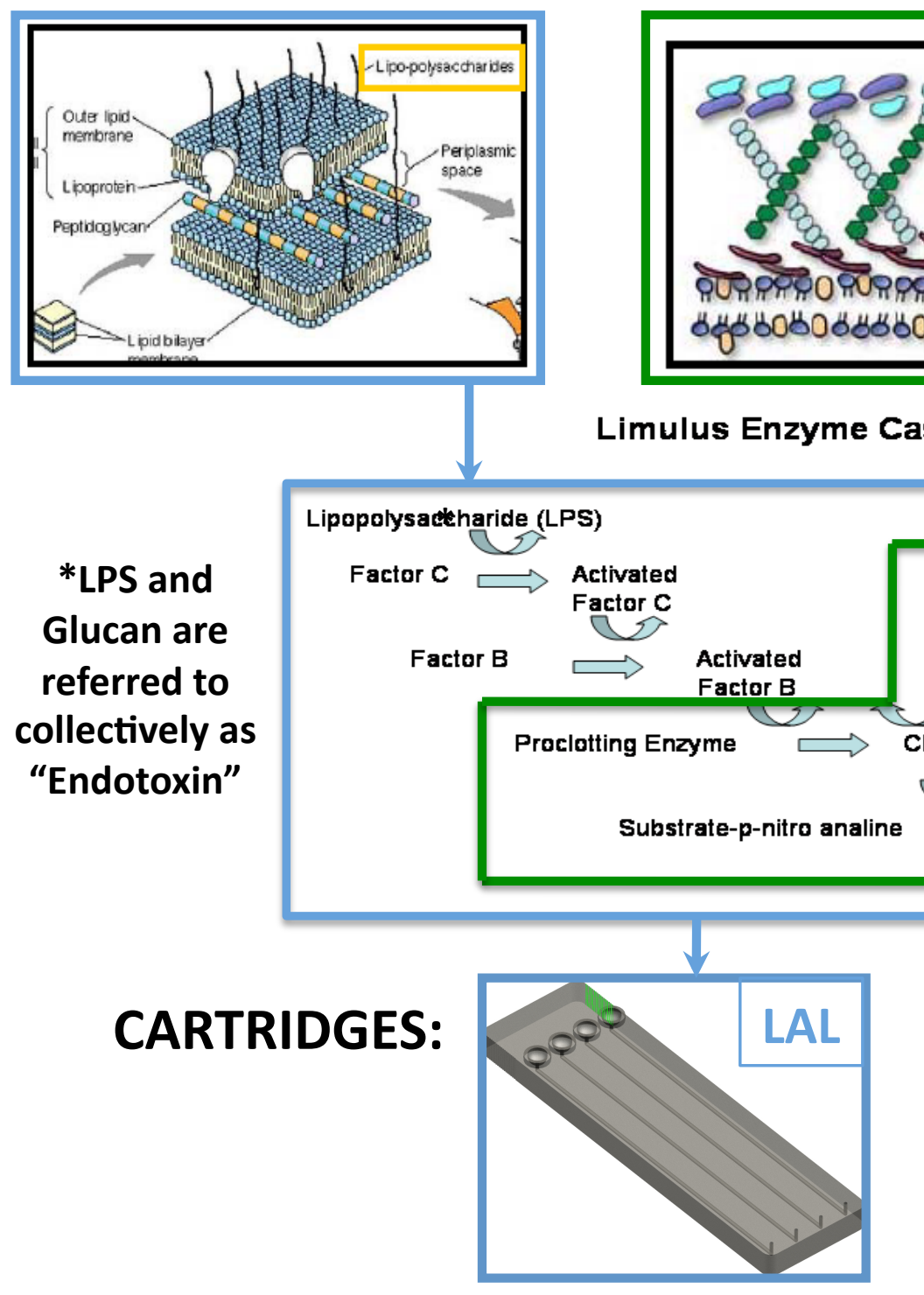

Fungi

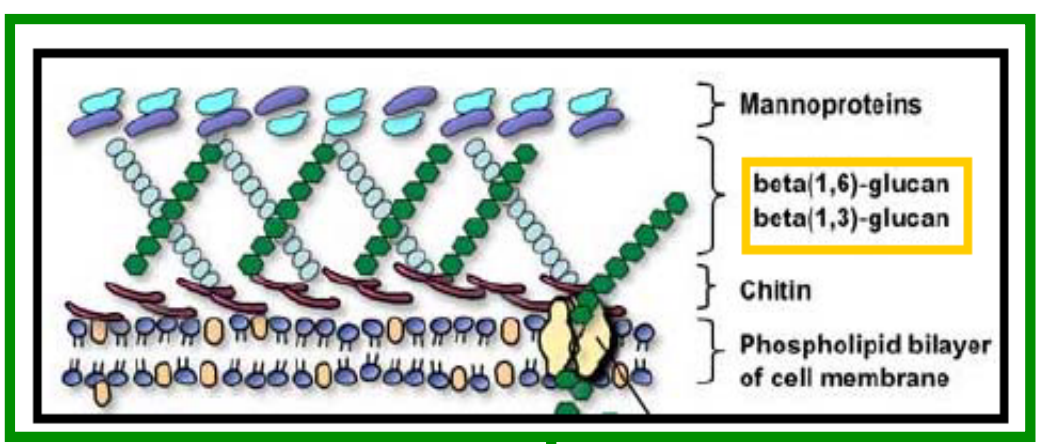

Gram-positive bacteria

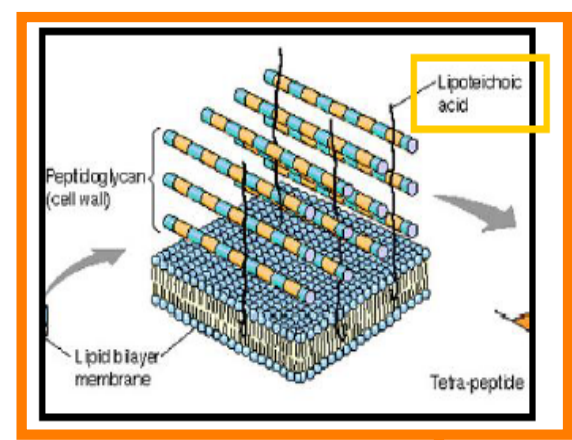

ape

\section{Pro-phenoloxidase (PPO) Cascade}

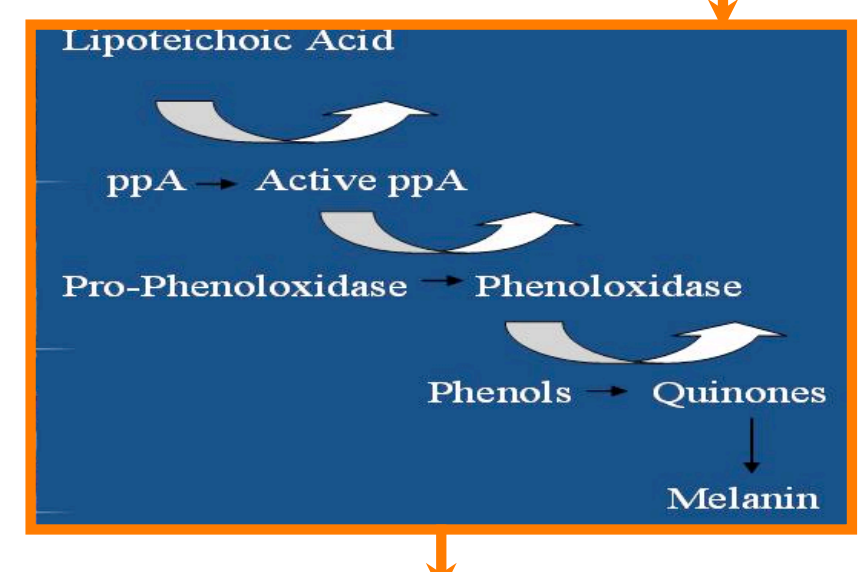

Bet-1,3 Glucan (color development)

$$
\text { ऽ }
$$

Activated $\rightleftharpoons$ Factor $\mathrm{G}$ Factor $\mathbf{G}$

(5)

p-nitro analine

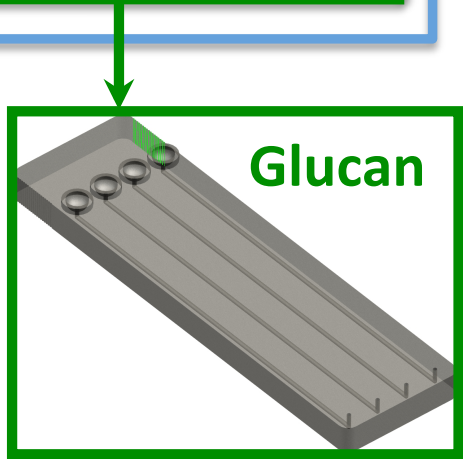

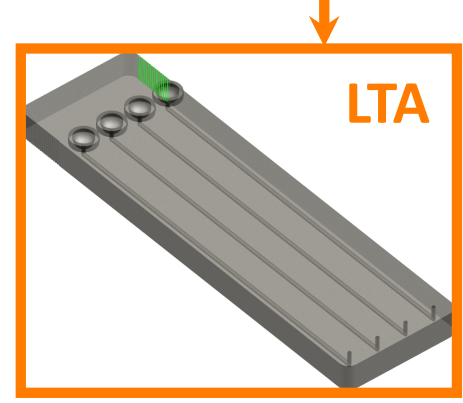




\section{LOCAD-PTS: Schedule and Operations Plan}

\begin{tabular}{|c|c|c|c|c|c|}
\hline Milestone & Start & End & $\begin{array}{c}\text { Number } \\
\text { of } \\
\text { Sessions }\end{array}$ & Crew & Mission \\
\hline $\begin{array}{l}\text { Launch LOCAD-PTS and } \\
\text { LAL Cartridges }\end{array}$ & $12 / 9 / 2006$ & - & - & STS-116 & STS-116 \\
\hline LAL Tests & $3 / 31 / 2007$ & 2/2/2008 & 10 so far & $\begin{array}{c}\text { Williams, } \\
\text { Tani, } \\
\text { Whitson }\end{array}$ & $\begin{array}{l}\mathrm{I}-14 \\
\mathrm{I}-15 \\
\mathrm{I}-16\end{array}$ \\
\hline Launch Glucan Cartridges & $3 / 11 / 2008$ & - & - & STS-123 & $1 \mathrm{~J} / \mathrm{A}$ \\
\hline Glucan Tests & $6 / 21 / 2008$ & $12 / 2008$ & 3 so far & $\begin{array}{c}\text { Chamitoff, } \\
\text { Fincke, } \\
\text { Magnus }\end{array}$ & $\begin{array}{l}\mathrm{I}-17 \\
\mathrm{I}-18\end{array}$ \\
\hline Launch LTA Cartridges & $11 / 14 / 2008$ & - & - & STS-126 & ULF-2 \\
\hline LTA Tests & $1 / 2009$ & $\begin{array}{l}\text { End of } \\
\mathrm{I}-18\end{array}$ & TBD & $\begin{array}{l}\text { Fincke, } \\
\text { Magnus }\end{array}$ & $\mid-18$ \\
\hline
\end{tabular}




\section{LOCAD-PTS: Objectives}

- Three Cartridge Types: LAL, Glucan, and LTA

- Each Cartridge Type used in two phases: Phase 1 and Phase 2

- Phase 1 objectives:

- Verify function of LOCAD-PTS Reader, swab system and procedures

- Check cleanliness of the swab kits

- Target same sites analyzed by CHeCS

- Compare LOCAD-PTS with contact slide data, with four swabs per site

- Phase 2 objectives:

- Survey a large number of diverse sites, with emphasis on crew choice

- Identify 'hot spot' sites, with one swab per site, no contact slides

- Overall objectives:

- Identify typical endotoxin/glucan/LTA levels throughout ISS ('space norms')

- Propose new requirements to supplement existing CFU requirements. 


\section{LOCAD-PTS Sampling Procedures}

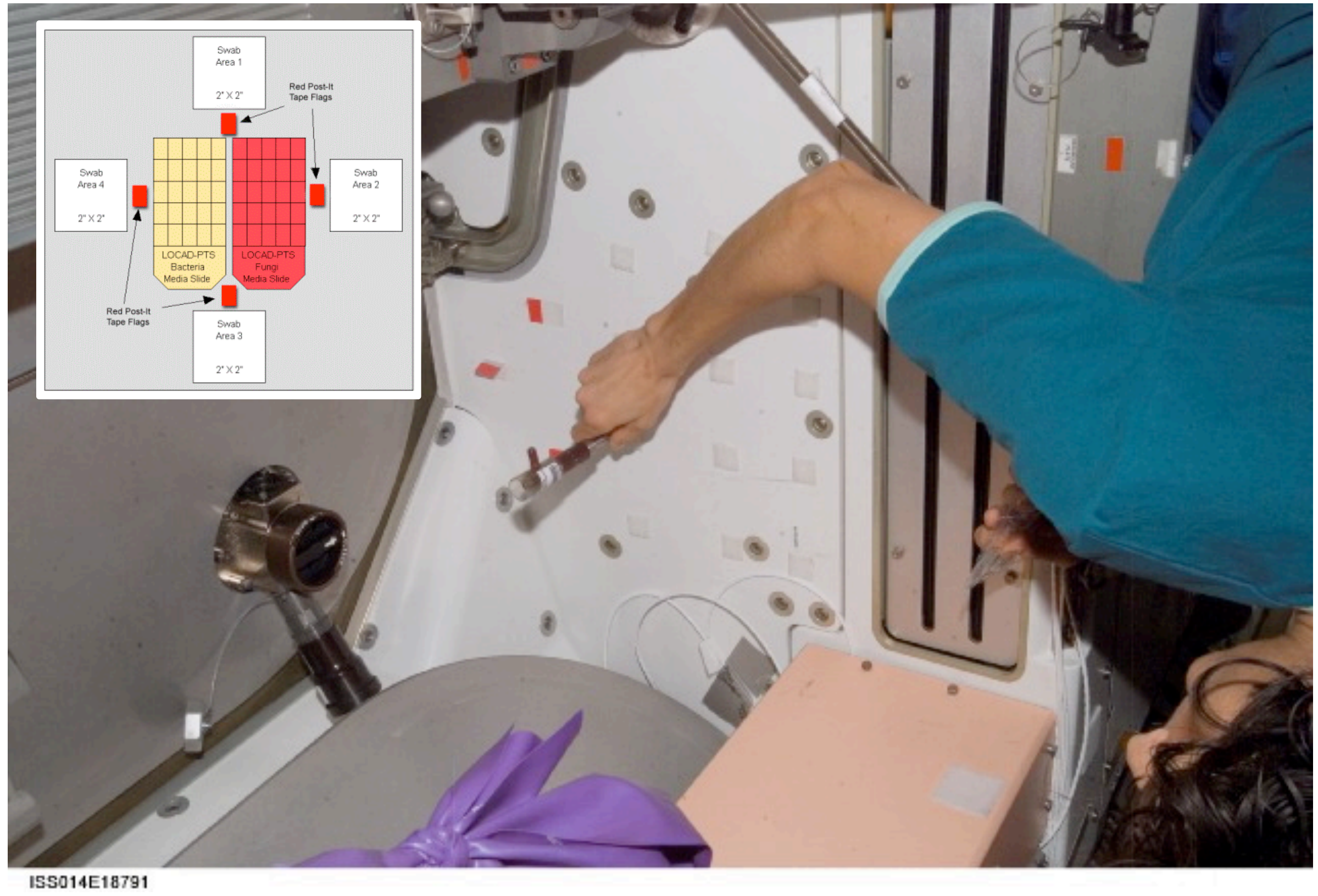




\section{LAL RESULTS}

March 31, 2007 to February 2, 2008 


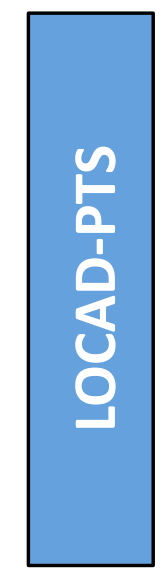

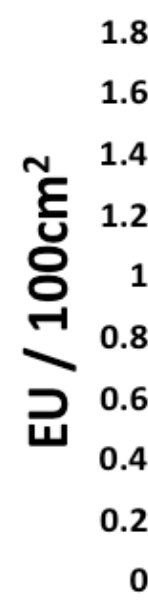

Endotoxin Units (EU) / $100 \mathrm{~cm}^{2}$
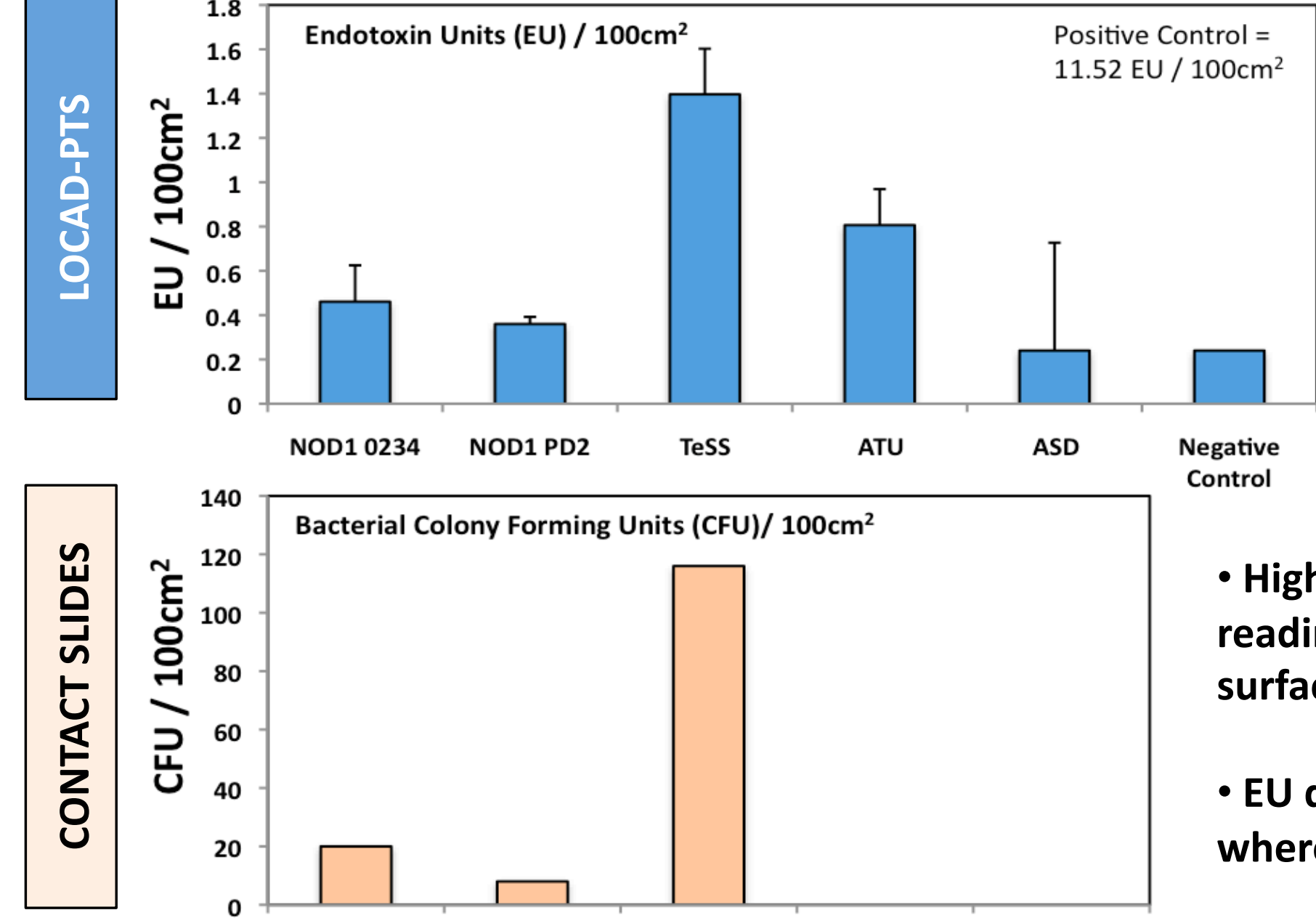

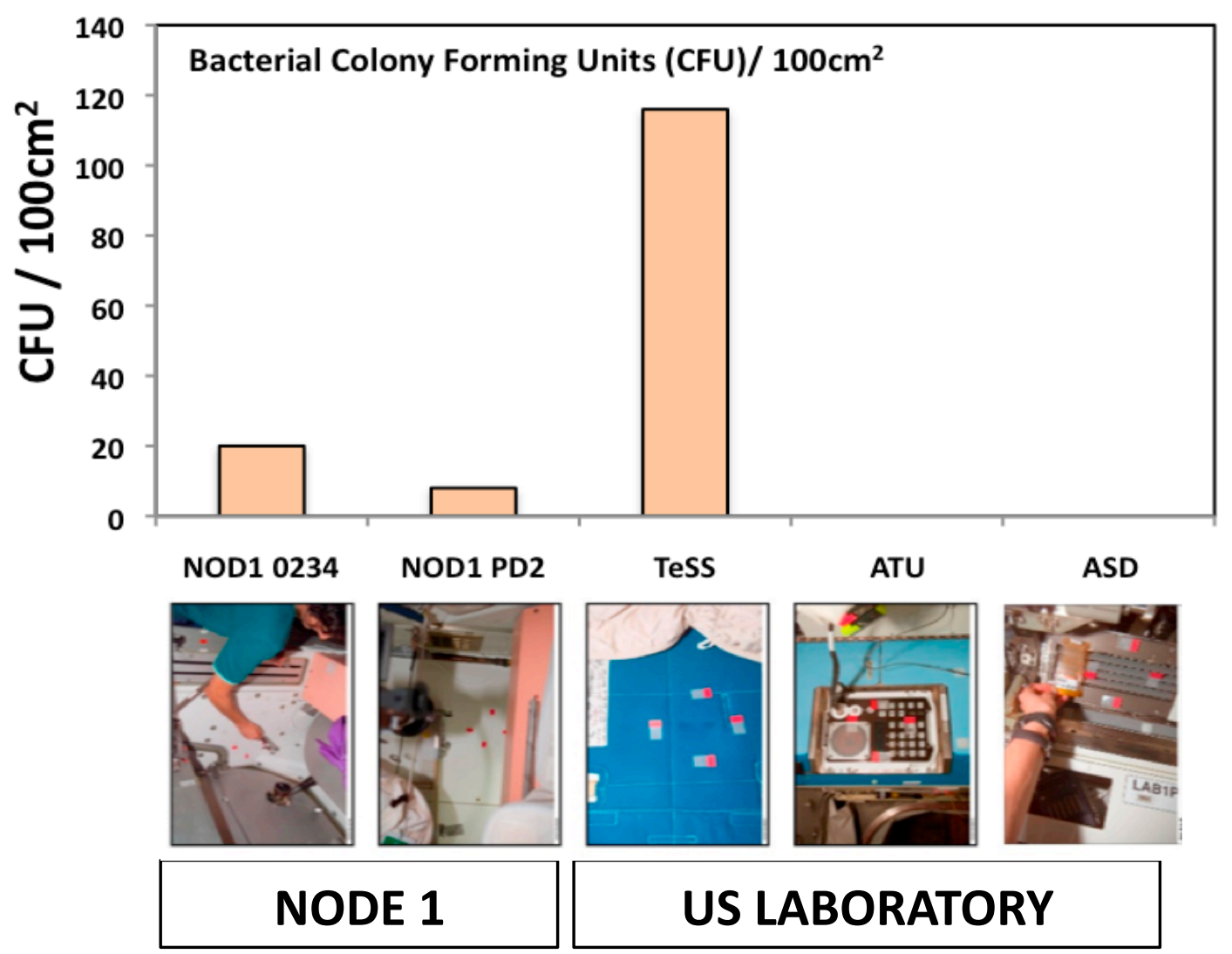

- Highest EU and CFU readings found on fabric surfaces

- EU detected at every site where CFU detected

- No 'correlation' expected between EU and CFU; and none observed 


\section{PHASE 2 DATA}

\section{LOCAD-PTS Detection Limits:}

Minimum $=0.24 \mathrm{EU} / 100 \mathrm{~cm}^{2}$

Maximum $=24 \mathrm{EU} / 100 \mathrm{~cm}^{2}$

\begin{tabular}{|c|c|c|}
\hline Category & EU per $\mathbf{1 0 0 \mathrm { cm } ^ { 2 }}$ & \# Sites \\
\hline Absent & $<0.24-0.5$ & 11 \\
\hline Low & $0.51-1.0$ & 6 \\
\hline Moderate & $1.1-10$ & 7 \\
\hline High & $10.1-24$ & 1 \\
\hline Off-Scale & $>\mathbf{2 4}$ & $\mathbf{0}$ \\
\hline
\end{tabular}

"Space norm": Absent/ with Moderate levels common in exercise/hygiene areas.

New surface requirement:

"ISS internal cabin surfaces shall be cleaned in-flight to a level that is $<24 \mathrm{EU} / 100 \mathrm{~cm}^{2 \prime \prime}$ (see later).

\begin{tabular}{|c|c|c|c|c|}
\hline Session & Date & Module & Location & $\mathrm{EU} / 100 \mathrm{~cm}^{2}$ \\
\hline \multirow{5}{*}{1} & \multirow{5}{*}{$\begin{array}{c}\text { Dee, 20, } \\
2007\end{array}$} & $5 M$ & Hygicne station wall & 2.0832 \\
\hline & & \multirow{3}{*}{ US Lab } & Laptop palmes rest & 1.1472 \\
\hline & & & 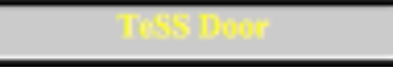 & 0.7162 \\
\hline & & & CEVTS (arm rest) & 2.2512 \\
\hline & & Node 1 & 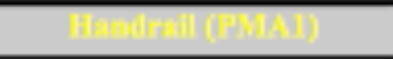 & 1.602 \\
\hline \multirow{6}{*}{2} & \multirow{6}{*}{$\begin{array}{c}\text { Dee, 21, } \\
2007\end{array}$} & \multirow{3}{*}{$5 M$} & Bathrosm Mirror & 14.736 \\
\hline & & & 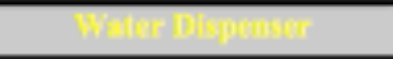 & 90.6912 \\
\hline & & & SM table tep & 2.7072 \\
\hline & & \multirow{3}{*}{ US Lab } & CEVIS & 1.3008 \\
\hline & & & LAB1 D5 Rack Face & $<0.24$ \\
\hline & & & 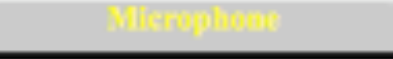 & $0.58 \times 2$ \\
\hline \multirow{5}{*}{3} & \multirow{5}{*}{$\begin{array}{c}\text { Dee. 24, } \\
2007\end{array}$} & \multirow[t]{2}{*}{ US Lab } & Air diffeser (P5O) & $<0.24$ \\
\hline & & & Thes ant & 0.2502 \\
\hline & & Node 1 & Behind panel (D2) & $<0.24$ \\
\hline & & Airlock & A/L vent & $<0.24$ \\
\hline & & $\mathrm{N} / \mathrm{A}$ & Negative control & $<0.24$ \\
\hline \multirow{5}{*}{4} & \multirow{5}{*}{$\begin{array}{c}\text { Jan. 26, } \\
20065\end{array}$} & $5 \mathrm{M}$ & Actrantinat & 9.90124 \\
\hline & & CS Lab & CEVIS (arm rest) & $<0.24$ \\
\hline & & $5 \mathrm{M}$ & Wall oppesite ACY mirror & 2.6064 \\
\hline & & $\mathrm{N} / \mathrm{A}$ & Negative control & $<0.24$ \\
\hline & & $\mathrm{N} / \mathrm{A}$ & Negative control & $<0.24$ \\
\hline
\end{tabular}
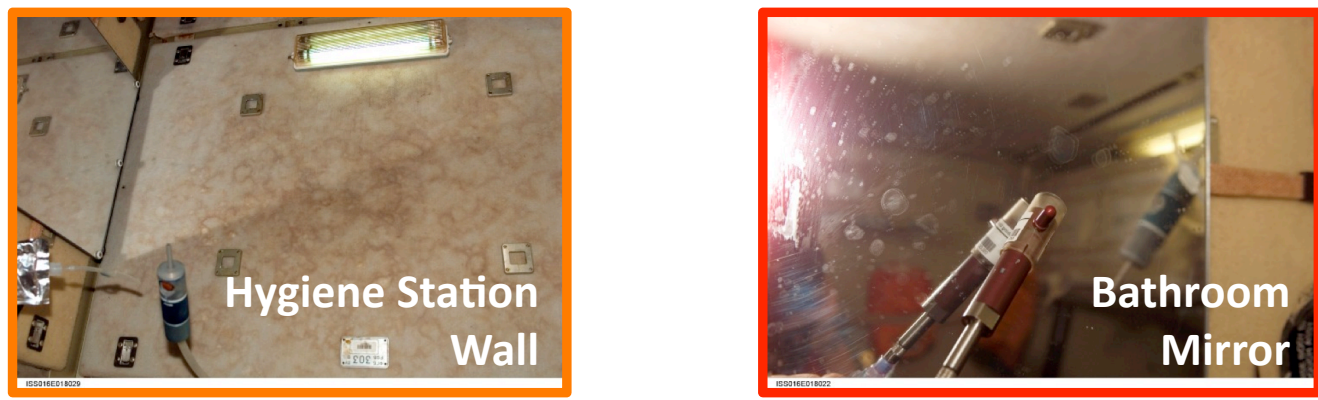


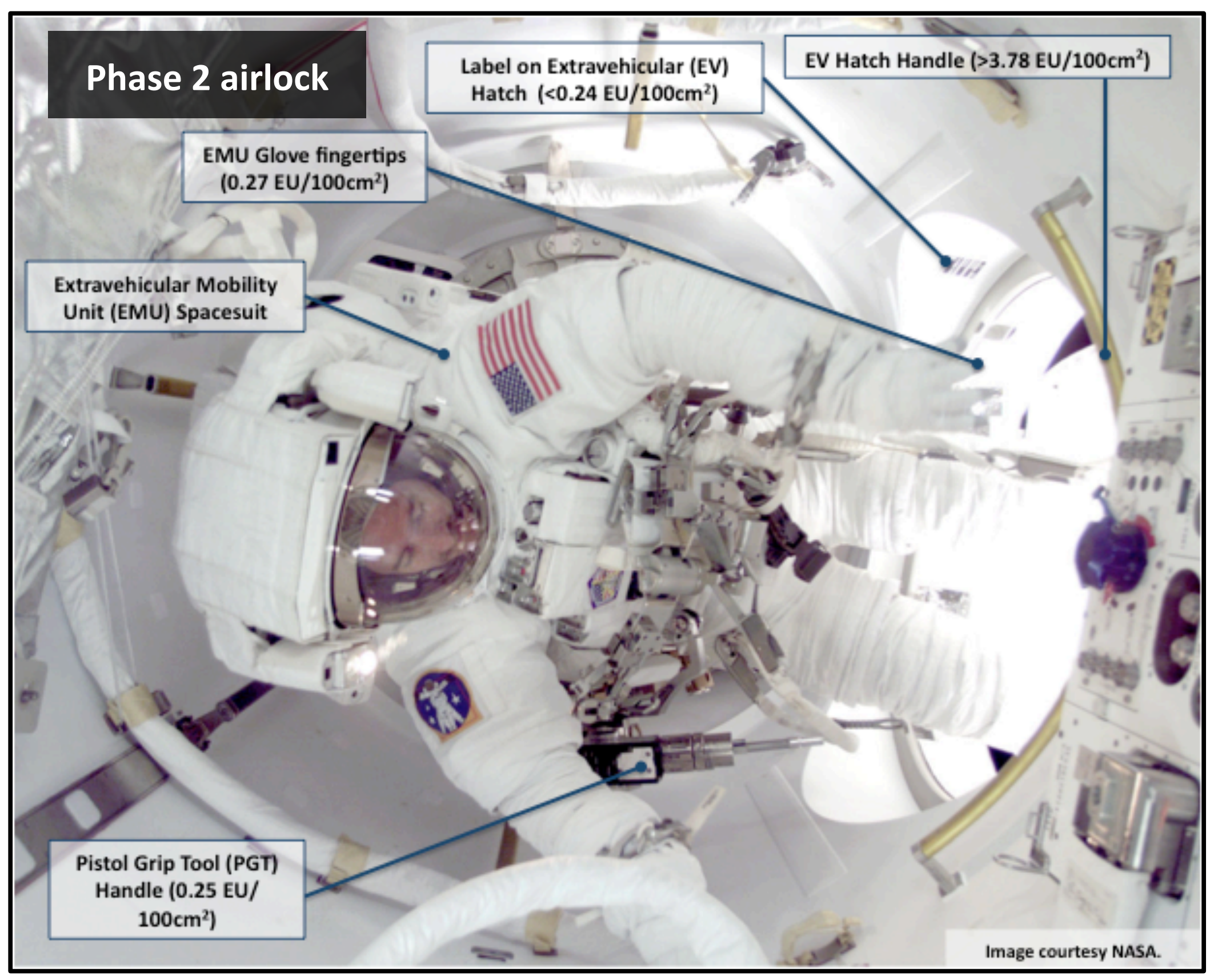




\title{
GLUCAN RESULTS
}

\author{
June 21, 2007 to December 1, 2008
}




\section{PRELIMINARY GLUCAN DATA}

\section{LOCAD-PTS Detection Limits:}

Minimum $=4.8 \mathrm{ng} / 100 \mathrm{~cm}^{2}$

Maximum $=480 \mathrm{ng} / 100 \mathrm{~cm}^{2}$

\begin{tabular}{|c|c|c|}
\hline Category & ng per $100 \mathrm{~cm}^{2}$ & \# Sites \\
\hline Absent & $<4.8-10$ & 3 \\
\hline Low & $11-80$ & 2 \\
\hline Moderate & $81-300$ & 3 \\
\hline High & $301-480$ & 0 \\
\hline Off-Scale & $>\mathbf{4 8 0}$ & $\mathbf{0}$ \\
\hline
\end{tabular}

\section{"Space norm":}

Absent/ tow, to Moderate

New surface requirement:

"ISS internal cabin surfaces shall be cleaned in-flight to a level that is $<480 \mathrm{ng} / 100 \mathrm{~cm}^{2 \prime \prime}$ (see later).

\begin{tabular}{|c|c|c|c|c|c|}
\hline Session & Date & Module & Location & $\begin{array}{c}\text { Fungal } \\
\mathrm{CFU} / 100 \mathrm{~cm}^{2} \\
\end{array}$ & $\begin{array}{c}\text { Glucan } \\
\left(\mathrm{ng} / 100 \mathrm{~cm}^{2}\right)\end{array}$ \\
\hline \multirow[b]{2}{*}{1} & \multirow{2}{*}{$\begin{array}{c}\text { Jun. 21, } \\
2008\end{array}$} & \multirow{2}{*}{ Node 1} & \multirow{2}{*}{ Panel 0234} & \multirow[t]{2}{*}{1} & $<4.8$ \\
\hline & & & & & 89.76 \\
\hline \multirow{4}{*}{2} & \multirow{4}{*}{$\begin{array}{l}\text { Sep. } 20 \text {, } \\
2008\end{array}$} & \multirow{4}{*}{ Node 1} & \multirow{4}{*}{ Panel PD2 } & \multirow[t]{4}{*}{0} & 27.31 \\
\hline & & & & & $<4.8$ \\
\hline & & & & & 86.88 \\
\hline & & & & & 16.85 \\
\hline \multirow[b]{2}{*}{3} & \multirow{2}{*}{$\begin{array}{c}\text { Dec. } 1, \\
2008\end{array}$} & \multirow[b]{2}{*}{$\mathrm{COL}$} & $\overline{\mathrm{ATU}}$ & \multirow{2}{*}{$\begin{array}{c}\text { Not } \\
\text { performed }\end{array}$} & 114.24 \\
\hline & & & $\begin{array}{c}\text { Biolab Glove } \\
\text { Box }\end{array}$ & & 6.05 \\
\hline
\end{tabular}

Columbus module (COL) Sites:

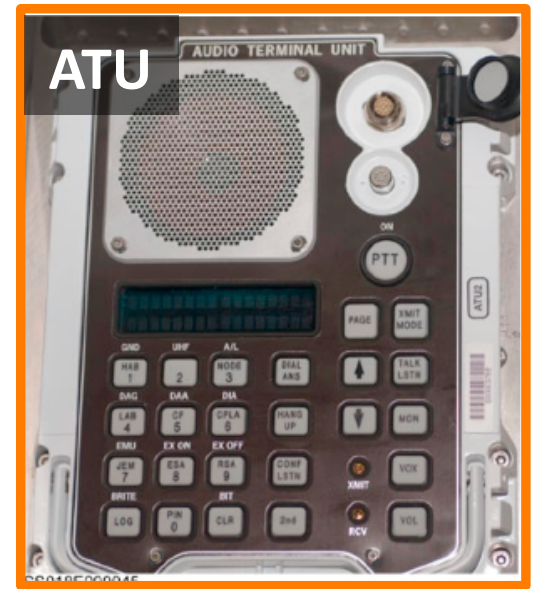




\section{Conclusions}

- Rapid culture-independent microbial analysis has been performed more than 12 times aboard the ISS since March 2007.

- Endotoxin and glucan found predominantly on fabric surfaces and sites associated with human activity, where microbial nutrients such as sweat, skin, food and water were prevalent.

- LOCAD-PTS acted as a reliable monitor of general biological material or "cleanliness"; and "space norms" determined for endotoxin and glucan on ISS cabin surfaces.

- There can be no general 'correlation' made between LOCAD-PTS parameters (EU or glucan) and CFU (viable cells), BUT, endotoxin was found at every site where CFU were detected on ISS.

- On the basis of LOCAD-PTS data collected so far, supplementary requirements are proposed for both general microbial monitoring and contamination control, for both ISS and Constellation missions.... 


\section{Proposed supplementary requirements}

for monitoring bacteria and fungi on internal cabin surfaces

\begin{tabular}{|c|c|c|c|c|c|c|}
\hline \multirow[t]{3}{*}{ Flight Stage } & \multirow{2}{*}{\multicolumn{2}{|c|}{$\begin{array}{l}\text { Existing Requirements } \\
\text { (CFU per } 100 \mathrm{~cm}^{2} \text { ) }\end{array}$}} & \multicolumn{4}{|c|}{ Supplementary Requirements (Units per $100 \mathrm{~cm}^{2}$ ) } \\
\hline & & & \multicolumn{2}{|c|}{$\begin{array}{c}\text { General* } \\
\text { (supplements existing) }\end{array}$} & \multicolumn{2}{|c|}{$\begin{array}{l}\text { Contamination control** } \\
\text { (Constellation) }\end{array}$} \\
\hline & Bacteria & Fungi & $\begin{array}{l}\text { Endotoxin } \\
\text { Units (EU) }\end{array}$ & Glucan (ng) & $\begin{array}{l}\text { Endotoxin } \\
\text { Units (EU) }\end{array}$ & Glucan (ng) \\
\hline Pre-flight & $<500$ & $<10$ & $<0.24$ & $<4.8$ & $<0.24$ & $<4.8$ \\
\hline In-flight & $<10,000$ & $<100$ & $<24$ & $<480$ & $<0.24$ & $<4.8$ \\
\hline
\end{tabular}

* This refers to general microbial monitoring requirements for internal cabin surfaces of ISS / Constellation vehicle. They are intended to supplement existing CFU requirements, with the aim of protecting crew health and spacecraft hardware.

** This refers to specific areas within a manned lunar/Mars lander that are periodically exposed to the lunar/Martian atmosphere and surface (e.g., airlock, spacesuit, and tools), with the aim of protecting future science and ensuring planetary protection. 


\section{Acknowledgements}

- Astronauts Suni Williams, Peggy Whitson, Dan Tani, Greg Chamitoff and Mike Fincke, who have operated LOCAD-PTS aboard ISS between March 2007 and December 2008.

- ISS Program Scientist Julie Robinson, ISS Increment Scientists Vic Cooley and Kenol Jules, and Christian Maender for facilitating on-orbit operations.

- Funding from Advanced Environmental Monitoring and Control (AEMC), Exploration Technology Development Program (ETDP) and the Exploration Systems Mission Directorate (ESMD).

- Mark Ott for technical review of this presentation and the whole JSC Microbiology Group (Duane Pierson, Bekki Bruce, Willy Wong, Victoria Castro, Antony Jeevarajan) and flight surgeon Jeff Jones for their continued support.

- Engineering and Project Support from Craig Gilmore, Yancy Young, Mark Shelton, Tim Broach and Curt Lewis at Teledyne Brown Engineering (TBE).

- Support from Payload Integration Managers (PIMs) Lorrie Hellier and Jeff Durham at Boeing.

- Funding for related projects of relevance to astrobiology and planetary protection from the Science Mission Directorate (SMD) 